\title{
Structural Design in the Work of Gaudí
}

\author{
Santiago Huerta \\ Department of Structural Design, Escuela Técnica Superior de Arquitectura, Universidad Politécnica de Madrid, \\ Avida Juan de Herrera 4, 28040 Madrid, Spain \\ Email: shuerta@aq.upm.es
}

Invited Paper: Received 3 April 2006; accepted 20 May 2006

\begin{abstract}
The work of Gaudí embraces all the facets of architectural design. The present paper studies the analysis and design of masonry arches, vaults and buildings. It is well known that Gaudí used hanging models and graphical methods as design tools. These methods can be traced back to the end of the 17 th Century. In addition, it was not original the use of equilibrated, catenarian forms. What was completely original was the idea of basing all the structural design in considerations of equilibrium. Gaudí also employed unusual geometrical forms for some of his vaults and ruled surfaces, showing a deep structural insight. Finally, he designed tree-forms of equilibrium for the supports of the vaults in the Sagrada Familia. In the present paper Gaudís equilibrium methods are studied with some detail, stressing their validity within the frame of Limit Analysis.
\end{abstract}

Keywords: Structural design; Gaudí; Masonry arches; Vaults; Catenarian forms; Equilibrium methods; Limit analysis

\section{Introduction}

Antoni Gaudí(1852-1926) was a Master Builder. His work covers all aspects of architecture: layout, ornamentation and stability. He also incorporates other arts: sculpture (particularly), painting, and photography. Any study of Gaudís work must embrace this global concept of the project. This article considers only one of the aspects of Gaudîs work: the design and calculation of structures. For Gaudí, structural design was an integral part of architectural design from its initial stages. It was not restricted, as was the usual case in those days, to a mere stability check. This paper will go through the different structural elements, studying the detail of Gaudi's design and calculation process and attempt to place his activity in a historical context.

\section{Catenary Arches}

From his first projects, Gaudí showed his originality and independence. In particular, he began to use systematically a type of arch not common in the western architectural tradition. Instead of using arches with a shape derived from

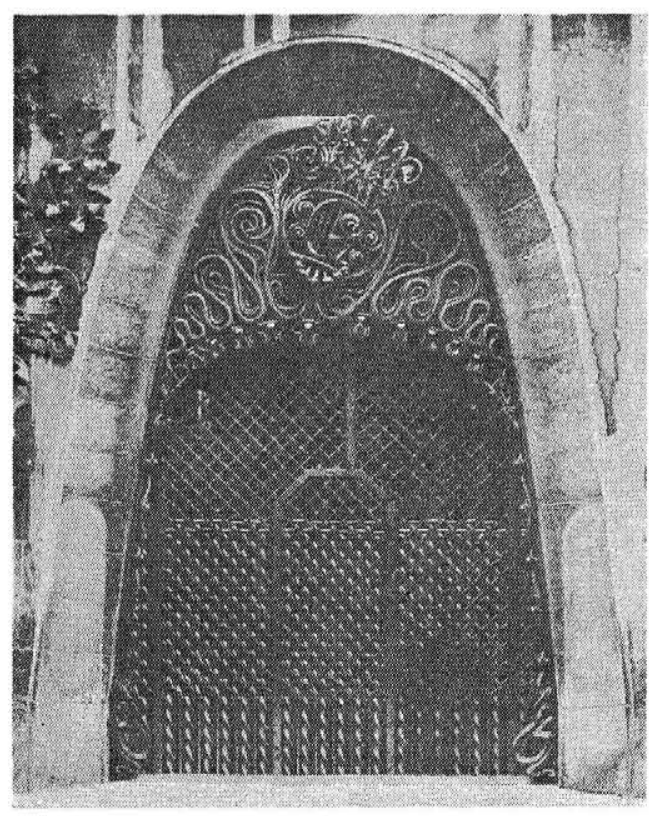

(a) the circle (roman, pointed, basket-handle, etc.), he used arches with non-circular shapes: parabolic or "catenary." These arches are already present in Gaudîs first buildings, seen in Figures 1 and 2.

Figure 1. Catenary arches: (a) Entrance to the Palacio Güell (Rafols 1929); (b) corridor in the School of the Teresianas (Tarragó 1991). 


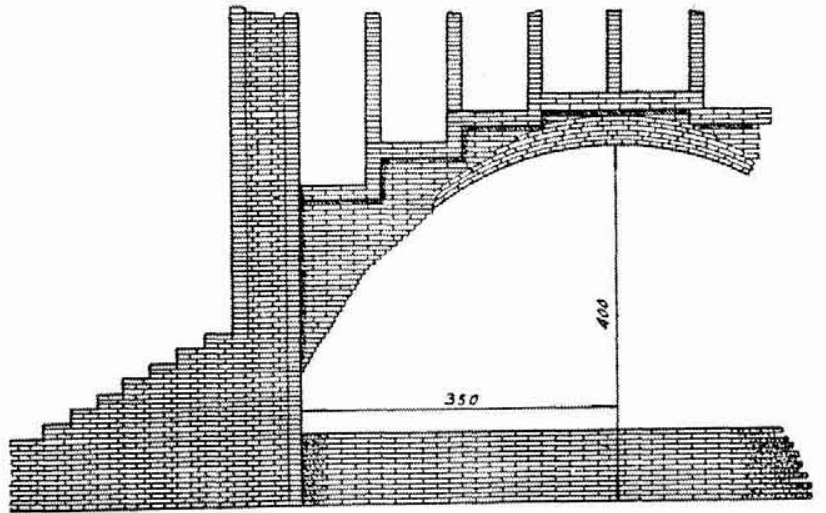

\section{Figure 2. Funicular arch for the cascade-fountain in the Casa Vicens (Bergós 1953)}

The use of these shapes has a mechanical origin, which goes back to the final years of the $17^{\text {th }}$ century. Around 1670 Hooke raised the following problem in a Royal Society Meeting (of which Newton, Wren and Boyle were also members): what is the ideal shape for an arch and how much thrust does it impose on its buttresses. Hooke (1675) gave the solution in an anagram included in a book about helioscopes: "As hangs the flexible line, so but inverted will stand the rigid arch," shown in Figure 3.

The idea is to understand the behaviour of arches by analogy with hanging cables: the equilibrium problem is, in fact, the same. This is one of the most brilliant ideas in the history of structural analysis. Soon after, Gregory (1697) writes an article about the shape of the catenary (the shape adopted by the hanging chain). He does not solve the problem (Bernoulli does in 1704; see Benvenuto 1991), but he extends Hooke's statement: the ideal shape for an arch is that of an inverted catenary "and when an arch of any other figure is supported, it is because in its thickness some catenaria is included" (Heyman 1999b). (It may be pointed out that the simple catenary is not a parabola, as in many texts on Gaudí both terms are used as synonyms; in fact, it has the shape of the hyperbolic cosine). It is a precocious statement, without proof, of the Lower Bound or Safe Theorem, which we will discuss in due course. Hooke's idea directly led to the use of simple hanging models for designing and calculating, for instance, arches for bridges. Some English engineers of the $18^{\text {th }}$ Century, notably John Robison, made use of this technique and Young (1807) covers and explains it in his Lectures on natural philosophy and the mechanical arts; see Figure 4.

This approach was not widely divulged in continental Europe, but it was still being mentioned in some French treatises of the $18^{\text {th }}$ century (for example, Bélidor 1729; Frézier 1737). In Germany, now in the $19^{\text {th }}$ century, Hübsch carries out some research on this idea and uses hanging models for sizing the buttresses of a church (Graefe 1985). Tappe (1818) published close to that time a book in which he proposed an architecture of catenary shapes that he never implemented, Figure 5 (Otto 1983, Graefe 1985).

Around 1840, the line of thrust theory is postulated (Moseley 1835, 1837; Méry 1840), making more rigorous the intuitive-experimental approach of the English engineers. In fact, this theory gave unity to the theory of arches, correlating lines of thrust and collapse mechanisms, which was the French approach through all the $18^{\text {th }}$ Century. Now it was possible to calculate and draw a line of thrust without models, using mathematical analysis or graphical methods. One of the first graphical analyses can be seen in Figure 6: the breakdown of forces is done directly on the drawing. The polygon of forces has been added by the author on the right. The use of polygons of forces separated from the funicular polygons is more convenient and became the general practice in the last quarter of the $19^{\text {th }}$ century. Graphical statics, the attempt to calculate structures using primarily graphic methods, was proposed by Culmann in his book Graphische Statik in 1866. However, the theory behind the graphical methods had been stated earlier by Rankine (1858) and Maxwell (1864). Graphical statics treatises were greatly divulged from 1870 .

This must have been the education that Gaudí received in his years as a student (1873-1878). Some mention to the analogy with cables (and possibly the use of models) and, with certainty, lectures about graphical analysis of arches and, perhaps, of vaults. However, Gaudí used the concept of catenary arches in a completely original way: to integrate the structural design in the process of architectural design. It is not a matter of verifying the stability of a certain design; it is a matter of projecting, from the start, using stable shapes. As far as we know, it is the first time that this attempt is made and exploited to its full capacity.

The practical problem is not that of the uniform catenary, an arch that supports itself: the problem is finding the shape of an arch that supports a certain load that may be defined by two lines (or surfaces), the intrados and the extrados. In many cases, the extrados is an initial datum and the loads are defined by the vertical
Figure 3. Robert Hooke's analogy between hanging chains and arches (drawing by Poleni 1748)
Figure 4. Bridge design using a hanging model (Young 1807). 
distance between the extrados and the intrados. The curve that defines the intrados must be of an equilibrated shape (Rankine called this curve the "transformed catenary" and we shall use this term from now on). In practice, this is the case for the design of a bridge or of an arch over a doorway, being part of a series of arches, or supporting a certain floor or vault. The exact mathematical solution for this problem had already been studied: for the case of bridges, by Villarceau (1853) and in a completely general way, for any load, by Rankine (1858).

The most common problem is finding the shape of a cable (or arch) that supports a load proportional to the vertical distance between its directrix and a horizontal extrados. This problem does not have a direct solution and the mathematics are somehow complex. The shape of the arch depends on the span/height relationship and on the thickness at the keystone. In Figure 7, we can see the equation of this line for the case of an arch with a horizontal extrados (Inglis 1951). For zero depth (a purely theoretical case), the shape given by this equation is an unusual one; for small depths the shape is very similar to that of the doorway at Güell Palace (Figure 1a). For depths similar to the span, the arch becomes parabolic.

Consequently, the use of parabolic arches at the Teresianas school (Figure 1b), is, according to the previous exposition, justified mechanically. However, it is evident that arches of other shapes, with the extrados filled in with a substantial wall, could contain the corresponding parabolas or catenaries (Gregory's statement above). Gaudí knew this, as is proven by the use of a symmetric catenary arch to support an asymmetric load, Figure 8. Gaudí found catenary and parabolic curves aesthetically pleasant and he used them even when he could have used other kinds of shapes.
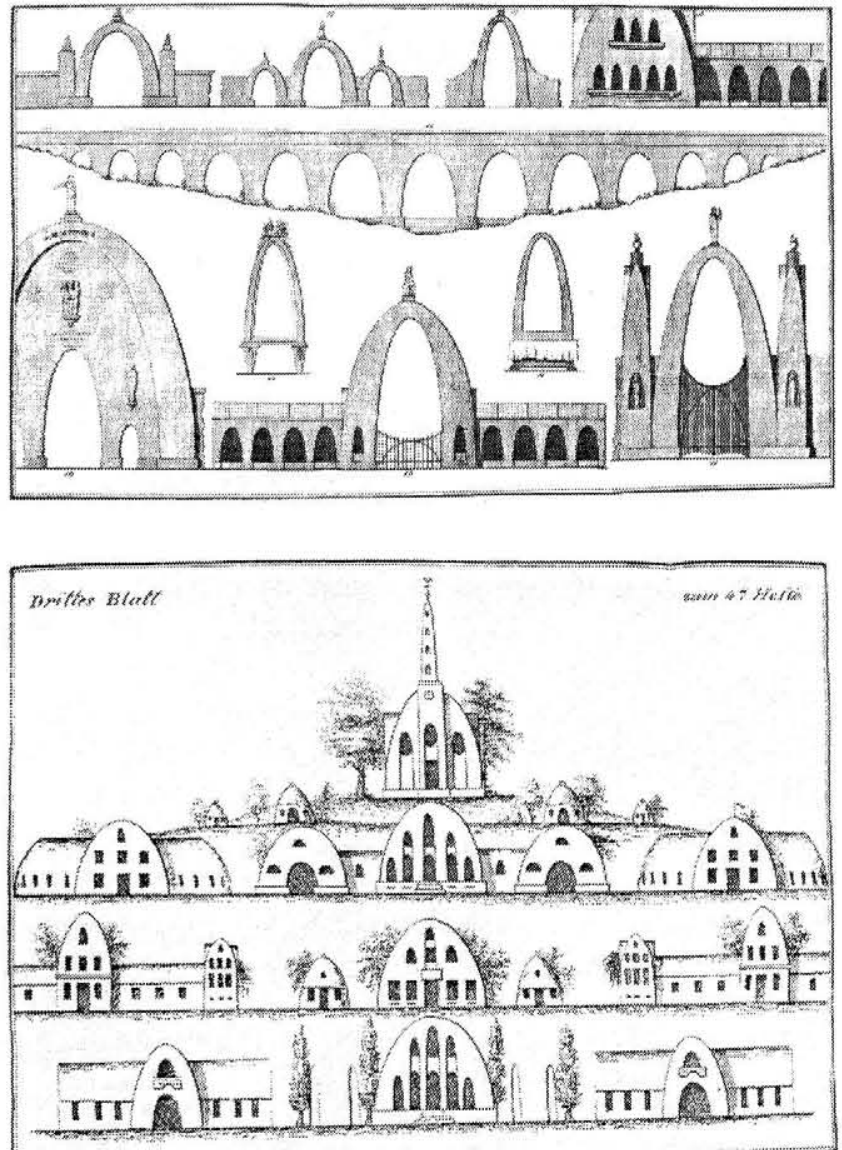

Figure 5. Tappe's proposal of a catenarian architecture (Tappe 1818-21).
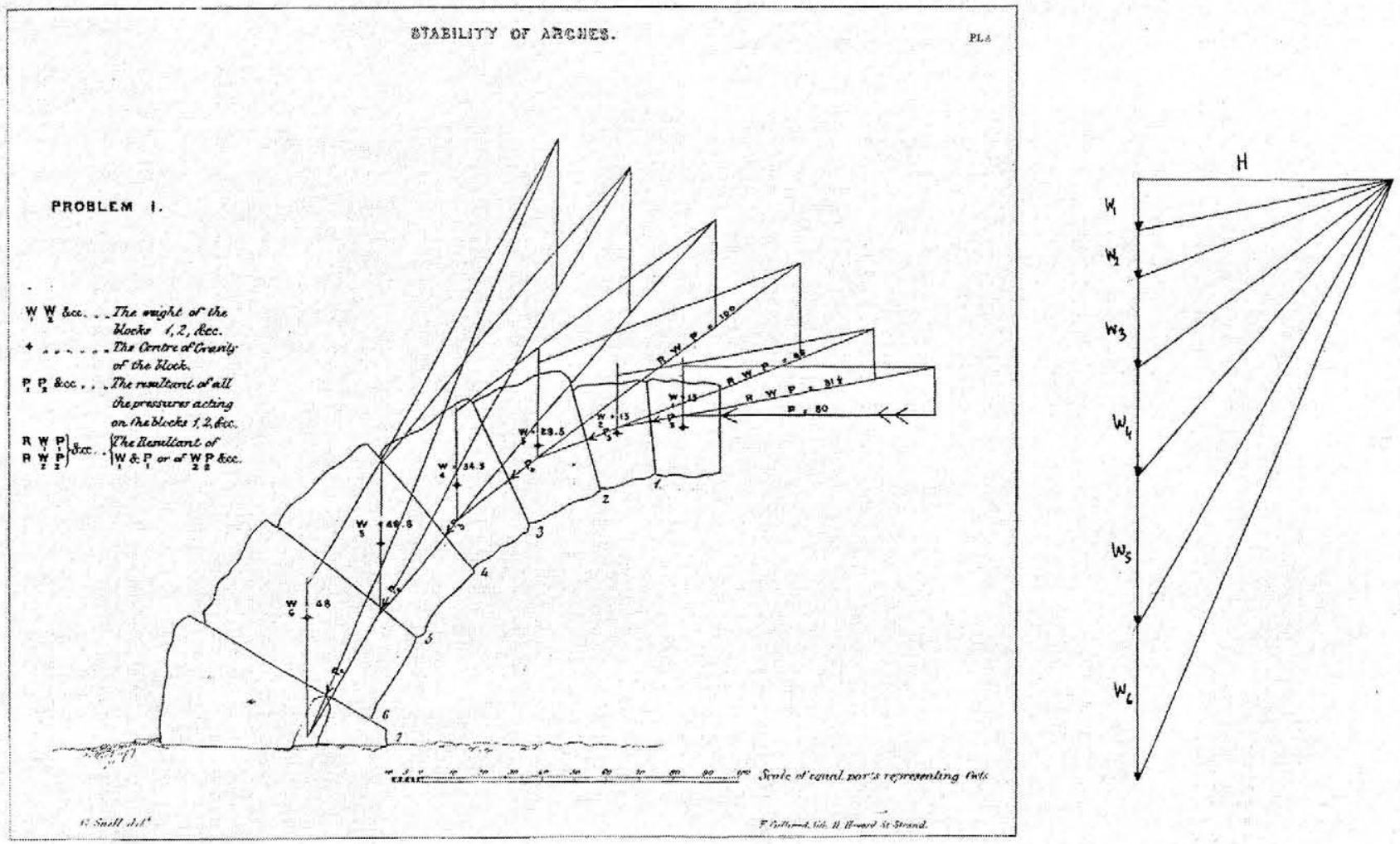

Figure 6. Line of thrust in a symmetrical arch: a) graphical construction using the parallelogram of forces (Snell 1846); b) corresponding force polygon, added by the author. 


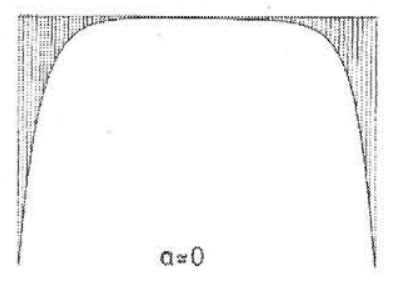

$$
y=a \cosh \left[\frac{2 x}{l} \cosh ^{-1} \frac{a+h}{a}\right]
$$
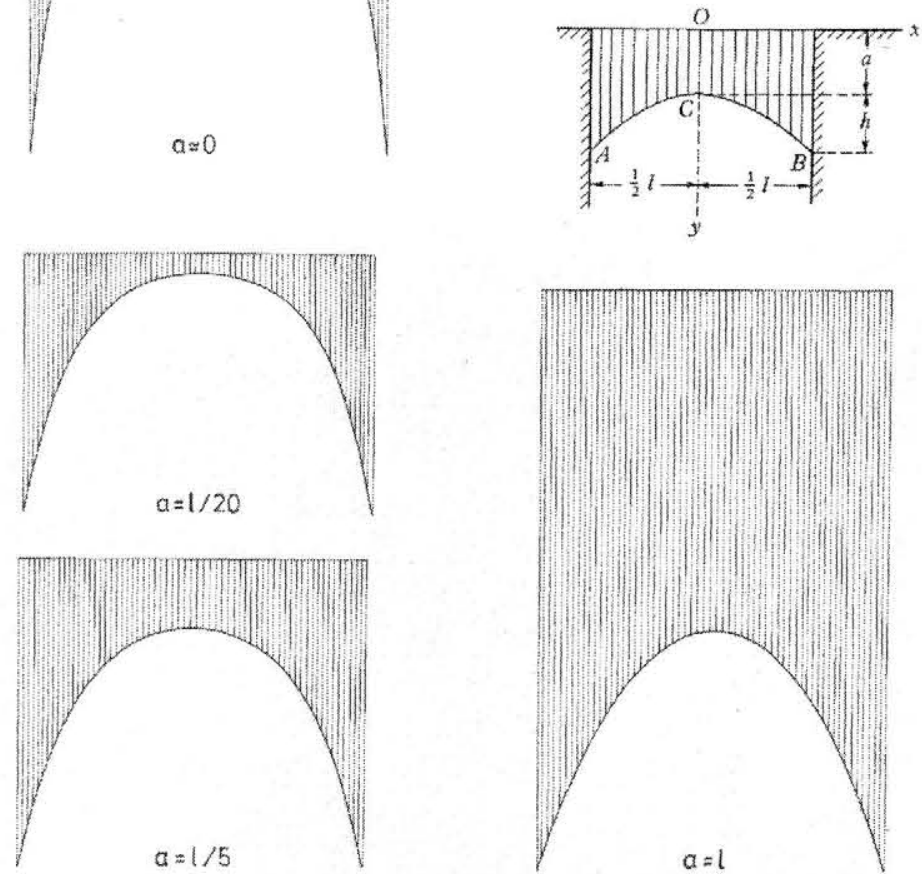

\section{$h=0,81$}

Figure 7. Arches with the form of a "transformed catenary," for different heights of the load. Mathematical formula by Inglis (1951); drawings by the author.

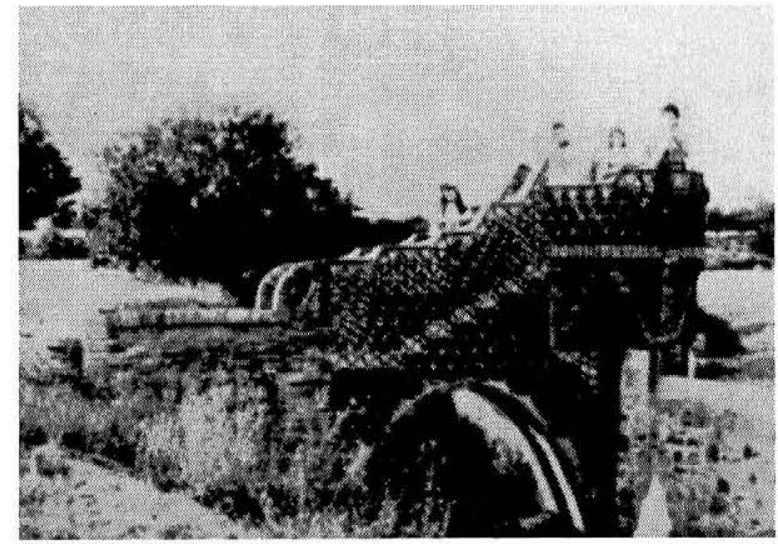

Figure 8. Gaudi's design for a pedestrian, catenarian, bridge of symmetrical form, which supports a non-symmetrical load (Giralt-Miracle 2002).

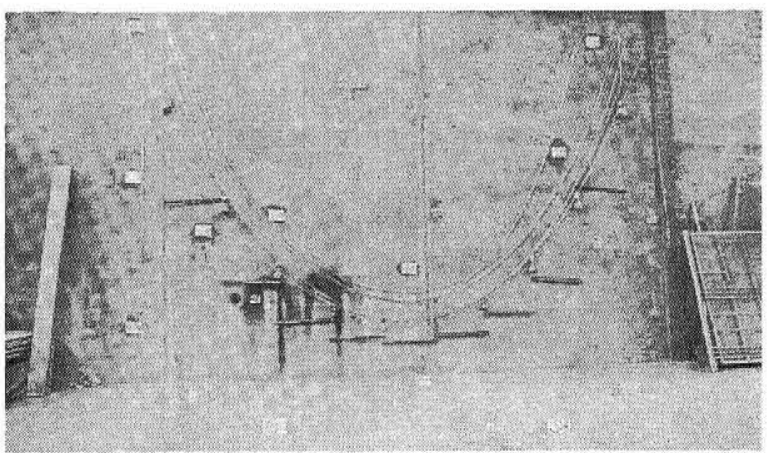

Figure 9. Hanging cables used by Gaudi in the design of the diaphragm arches of the Mila house (Roca et al. 1996).

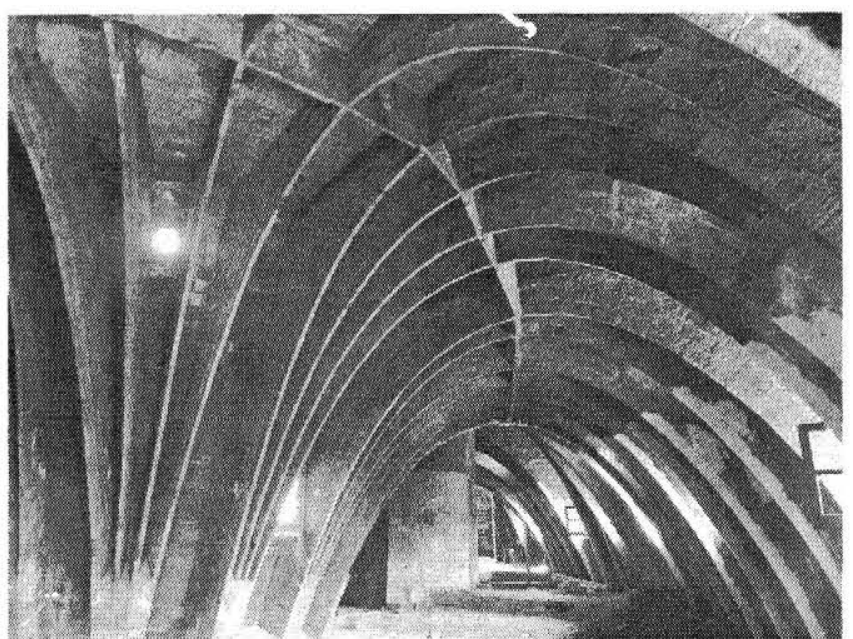

Parabolas, even simple catenaries, can be drawn directly. Transformed catenaries imply complex mathematical calculations or using iterative graphic methods or hanging models. Gaudí needed a design tool that allowed him to carry out quick calculations and alter the design at will. The mathematical calculations, necessarily tedious in those days, contradicted these requirements. Thus, Gaudí used the other two methods; the evidence is both on his statements recorded in conversations with his disciples, Bergós (Codinachs 1982) and Martinell (1969), and on calculation sketches and photographs. Figure 9, for instance, is a photograph of the hanging cable models used in the design of the diaphragm arches at the loft in the Mila house in Barcelona, Figure 10.

The moderate size of the arches at the Mila house meant they could be plotted on the wall. The process is not direct: first, a simple cable is hung and the loads that would act on it are calculated, measuring the vertical distances (self-weight of the walls at the haunches) and adding the corresponding weight of the floor. These weights are added to the cable, causing a change on its shape. Vertical distances are measured again and the self-weight modified. The cable under these loads adopts a shape that is very close to the exact mathematical shape. This iterative process can also be carried out using graphical statics and some of the corresponding sketches were published by Puig Boada (1976) and Tomlow (1989), Figure 11.

If some of the loads are not vertical, graphical methods could be more convenient. IGaudí used them in the design of the porticos and retaining walls at Parque Güell. On the drawing, Figure 12, 

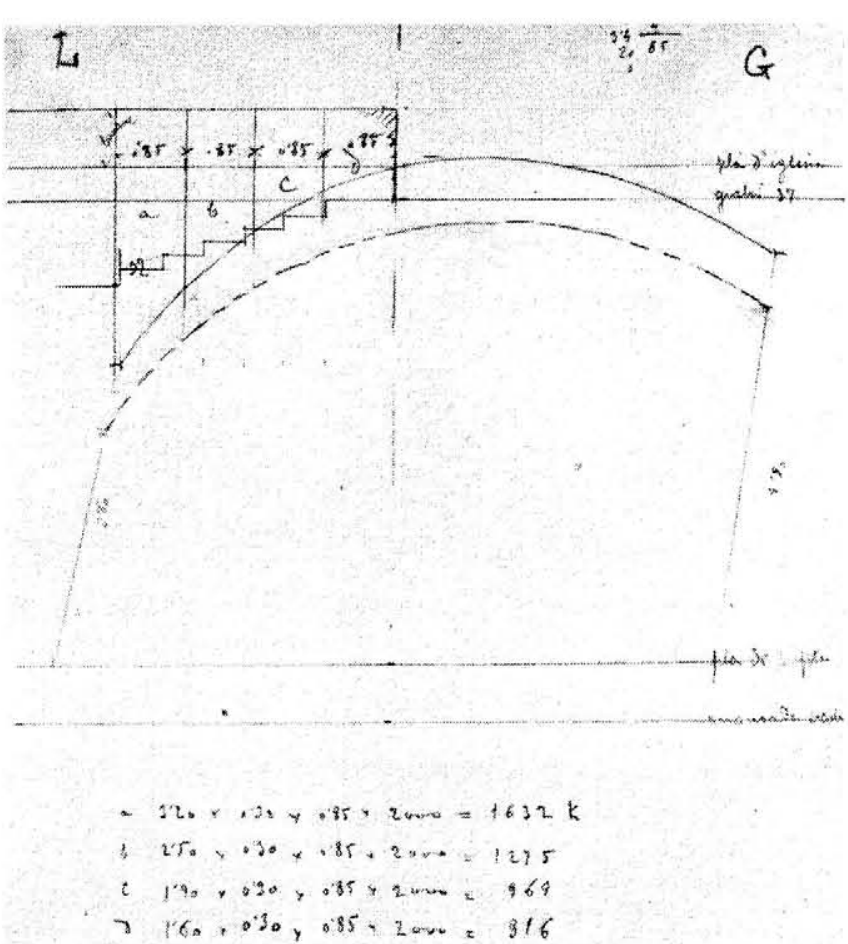

Figure 11. Church of the Colònia Güell. Draft of Gaudi's calculations for the design of one of the arches (Puig Boada 1976).

published by Rubió i Bellver (1913), it can be seen that a method similar to that of Figure 6 was used, on which the breakdown of forces is done directly on the picture, instead of drawing a separate polygon of forces, as was the general practice. Gaudí must have used it frequently (according to Rubió, he was already using it before 1880) since it appears on other drawings, for instance, on the cal-
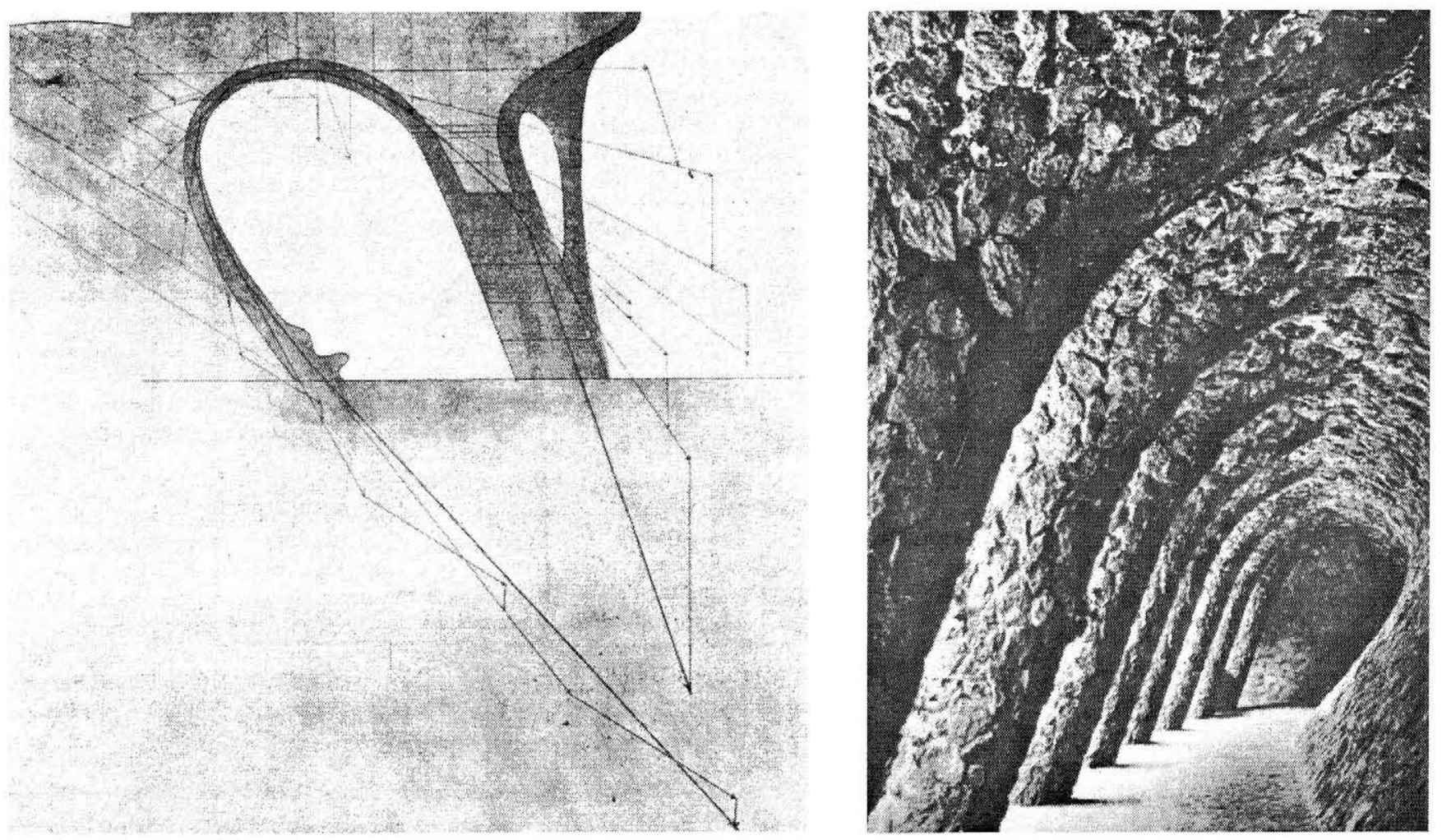

Figure 12. Graphical design of the retaining walls of the Parque Güell in Barcelona (Rubió 1913, Tarragó 1991).

culation for the western façade of the Sagrada Familia, Figure 13. The method was used by Rubió Bellver (1912) on his mechanical analysis of the cathedral in Palma de Mallorca. Its origin is likely to be in Planat's manuals (1887 and 1906), greatly divulged in Spain, Figure 14. The drawing becomes complex, but has the advantage of keeping all the elements visible on the same diagram.

Figure 13. Graphical statics of the western façade of the Sagrada Familia (Rafols 1929). 
Gaudí did not prefer one method to the other. There is an evident desire to investigate and consider the problem from different perspectives. The combined use of graphic methods and models allowed Gaudí to obtain a deep understanding of stability and shape problems in masonry arches. They appear to have been used systematically. This way, he tells Martinell (1969): "I calculate everything."

\section{Vaults and Buildings: Hanging Models}

The design and calculation of arches (or barrel vaults) is a problem that can be solved on a two dimensional plane. A vault is a spatial, three dimensional, problem. Following his investigations on the design of arches, Gaudi studied the more general problem of designing vaults and, finally, complete buildings with equilibrated shapes.

Graphical statics allowed the analysis of vaults of fixed shapes. From the decade of 1870 , vaults are analysed by dividing, or "slicing," them into simple arches (see, for example, Wittmann 1879). Thus, to analyse a cross vaulting we imagine each of the barrels "sliced" or "cut" in a series of elementary arches. These arches are supported on the cross arches, which transfer the loads to the springings, as seen in Figures 14 and 18. In this way, a feasible equilibrium solution is obtained from the infinite range of possible solutions that can exist for an indeterminate structure.

This idea of imagining three-dimensional vaults as being the sum of a series of arches obtained by "slicing" the structure by a family of planes must have been applied for the first time by Hooke in the last quarter of the $17^{\text {th }}$ century, while working with Wren in the design of St. Paul's dome. Just as it happened with the case of the catenary arch, he couldn't find the correct mathematical expression, but some of the previous designs for the dome show the use of dome-like catenary shapes (the simple catenary is substantially different from the catenary surface for a dome). Hooke eventually stated that the ideal profile for a dome is that of a cubic parabola, which is very close to the correct solution as can be seen in Figure 15 (Heyman 1998). Heyman has found the evidence of Hooke using the cubic parabola in one of Wren's designs (Heyman 2003). It can be seen in Figure 16 that the catenary drawn and the ordinates and abscissas show that it is a cubic parabola; this crucial fact had been overlooked until now (Graefe 1986, publishes the drawing but doesn't comment on it). The drawings of catenaries in Wren's designs were only

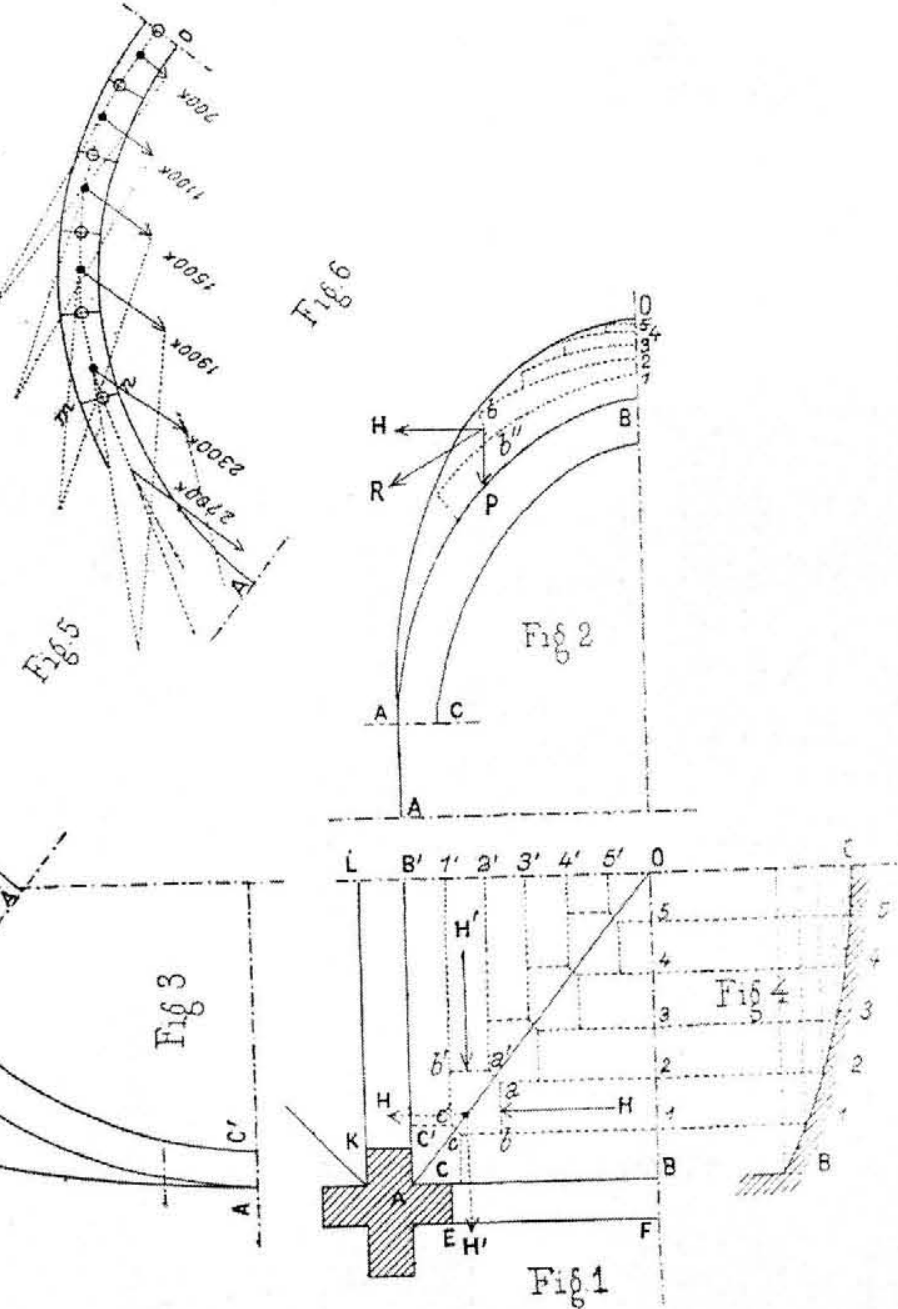

Figure 14. Graphical analysis of a cross vault (Planat 1887)

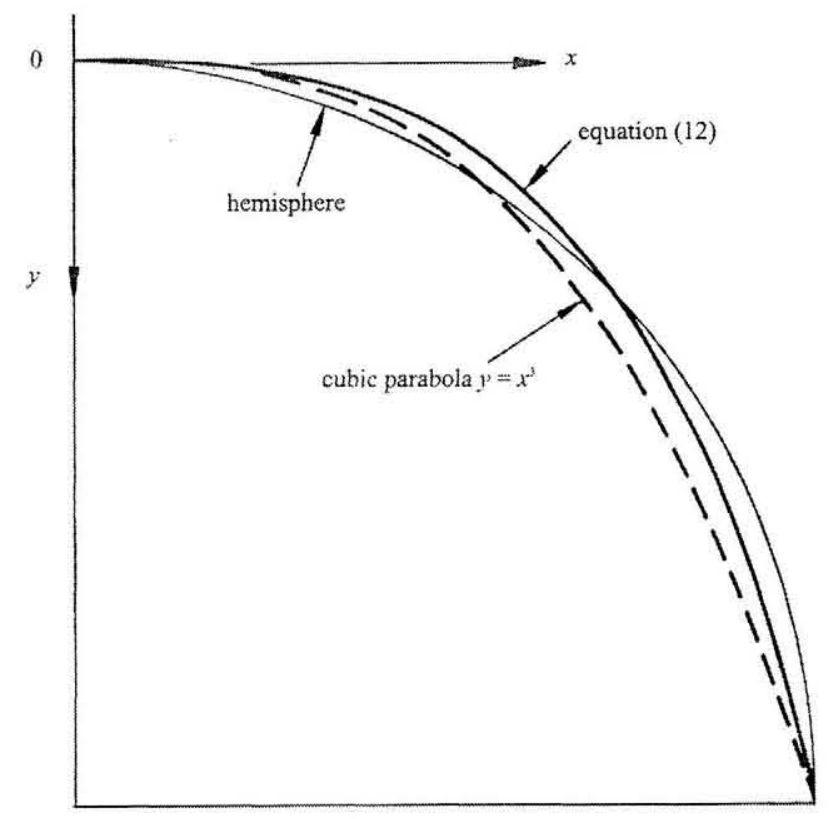

Figure 15. Ideal profile of a dome. Comparison between the exact solution (eqn. 12), the hemi-spherical form and Hooke's cubic parabola (Heyman 1998). 


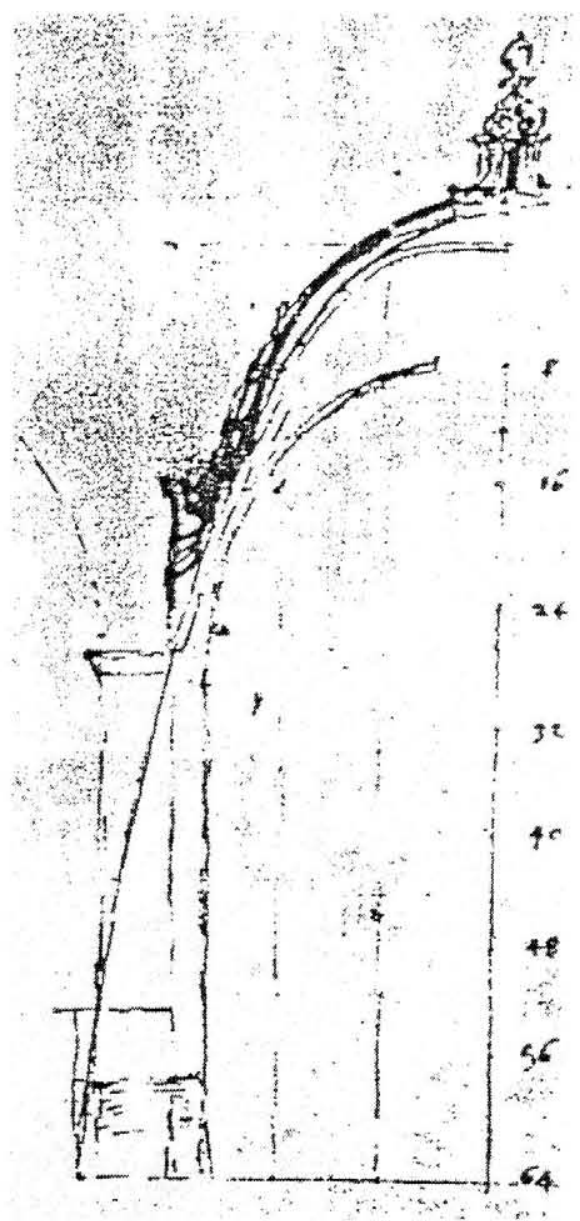

Figure 16. Hooke's cubic parabola drawn in one of Wren's designs for the dome of

St. Paul. The numbers on the right side represent the ordinates of the intermediate shell (Graefe 1986).

published in the second half of the $20^{\text {th }}$ century, and did not have any influence in later years.

The "slicing technique" was suggested for the first time in a publication by Frézier (1737), in the chapter about vaults of his treatise on stereotomy, and was applied for the first time by Poleni (1748) in his stability analysis of St Peter's dome. Poleni imagined the dome to be cut in fifty segments: every two opposed segments formed an arch; if finding a "catenary" inside it was possible, then the arch would stand and consequently so would the dome. Poleni, no doubt conscious of the difficulty of the mathematical analysis, obtained the curve using a hanging model, Figure 17. Towards the end of the $18^{\text {th }}$ century, Soufflot and Rondelet appear to have employed catenary forms in some designs for the Pantheon in Paris. Tomlow (1993) has proven this technique was used in the design of a dome in 1837. Not much more is to be found in the literature; Poleni's genius analysis went unnoticed.

The mathematical analysis of equilibrated dome shapes started in the $18^{\text {th }}$ century; Bouguer (1734) found the mathematical expression that Hooke was looking for and stated, for the first time, what today we would call "membrane" theory or approach. During the final years of the $18^{\text {th }}$ century and the beginning of the $19^{\text {th }}$ century, some engineers developed a mathematical theory for domes that was never put into practice (see, for instance, Bérard 1810).

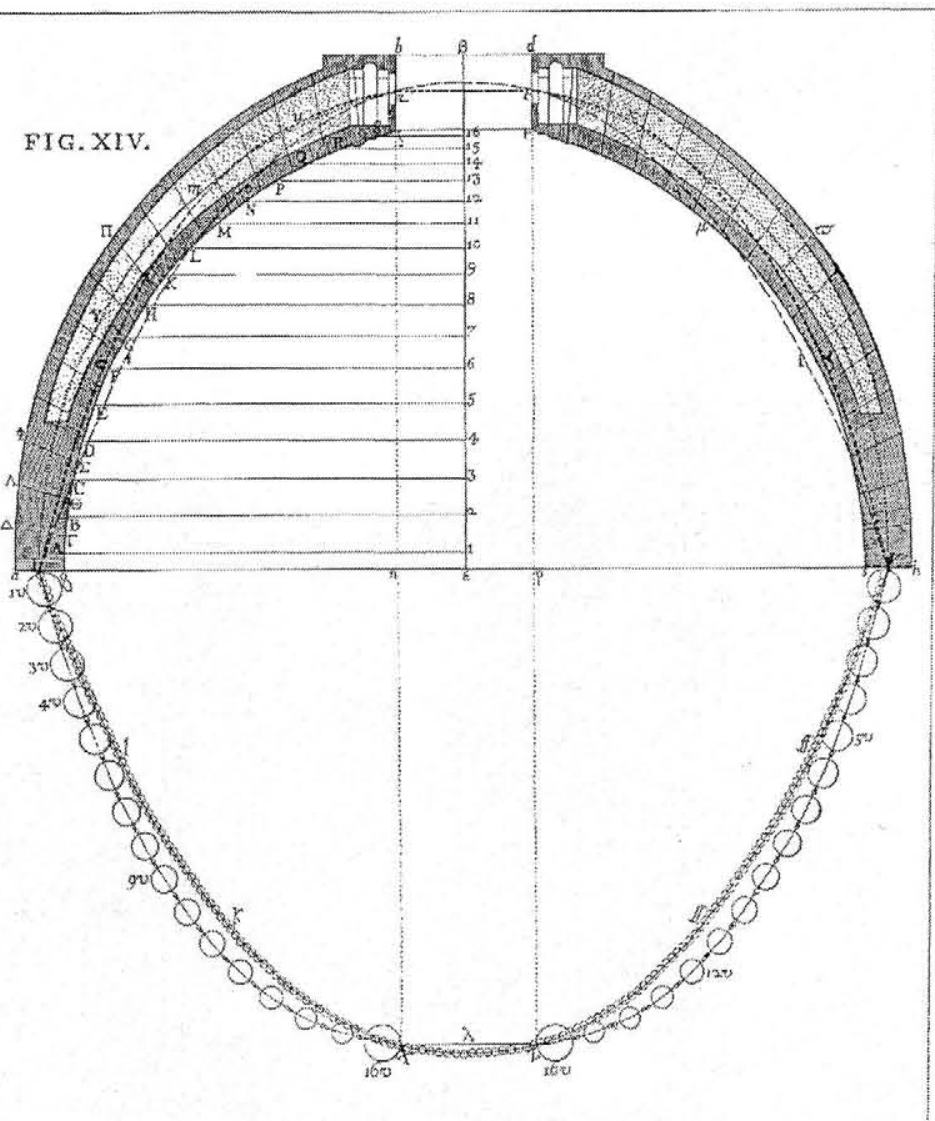

Figure 17. Poleni's hanging model constructed to check the stability of St. Peter's dome (Poleni 1748).

Gaudí could have heard of Poleni's analysis. Regarding other types of vaults, he must have been familiar with some of the first graphic analysis of vaults carried out in the 1870 's, which were divulged very fast throughout Europe: for the first time there was an available and reliable calculation method to verify the stability of existing structures or new designs, and Rubió Bellver (1913) comment about Gaudís interest on graphical statics is explicit. Around 1900 works by Mohrmann on the Gothic structure (Ungewitter/Mohrmann 1890) and by Koerner (1901) on vaults in general, just to mention two books that had great diffusion, provided an analysis of the most usual vault shapes.

However, Gaudí did not want to apply the traditional method: first, the vault is designed, giving it a certain shape and dimensions (in the style considered to be most appropriate, neo-gothic, neo-Byzantine, neo-Renaissance, etc.) and, then, its stability is checked using graphic methods. Gaudí, as with arches, wanted to apply a design method that allowed him to obtain equilibrated forms directly. Graphic statics, as mentioned already, can be used comfortably in two dimensions (on the drawing surface). To fix the position of a line in space three projections are needed, thus making space problems very laborious to solve.

Gaudí soon realised that, in the most general case, the only possible solution was to use space-hanging models. The idea is, most likely, Gaudís original. While hanging models for arches are common in the literature of the second half of the $19^{\text {th }}$ century, there is only one mention of the use of hanging models for studying the behaviour of vaults. In his additions to Ungewitter's handbook on 

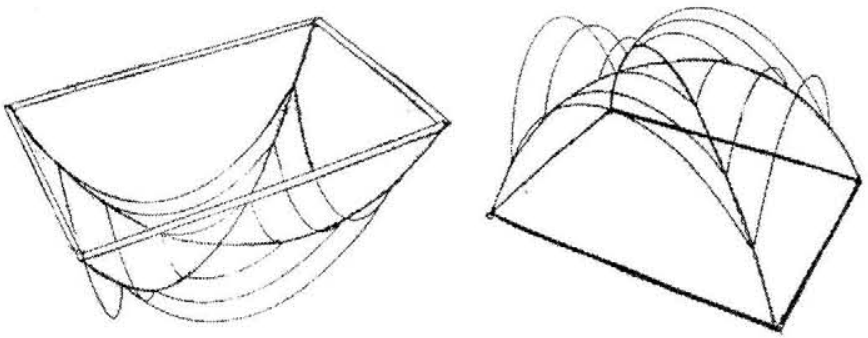

Figure 18. Hanging model of a gothic cross vault (Beranek 1988).

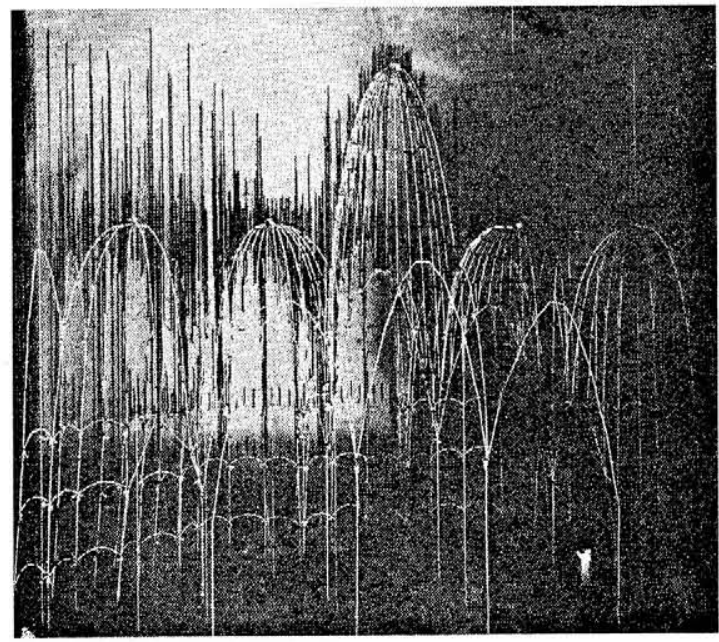

Figure 19. Preliminary hanging model made by Gaudi for the church of the Colonia Güell (Rafols 1929).

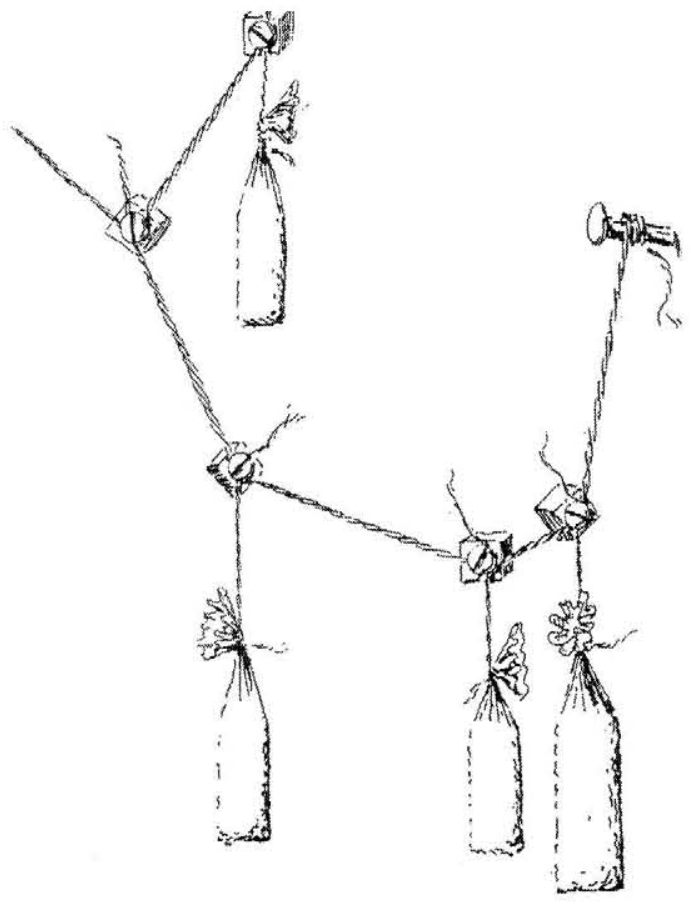

Figure 20. Use of sachets to apply loads to the hanging model (Rubió I Bellver 1913).
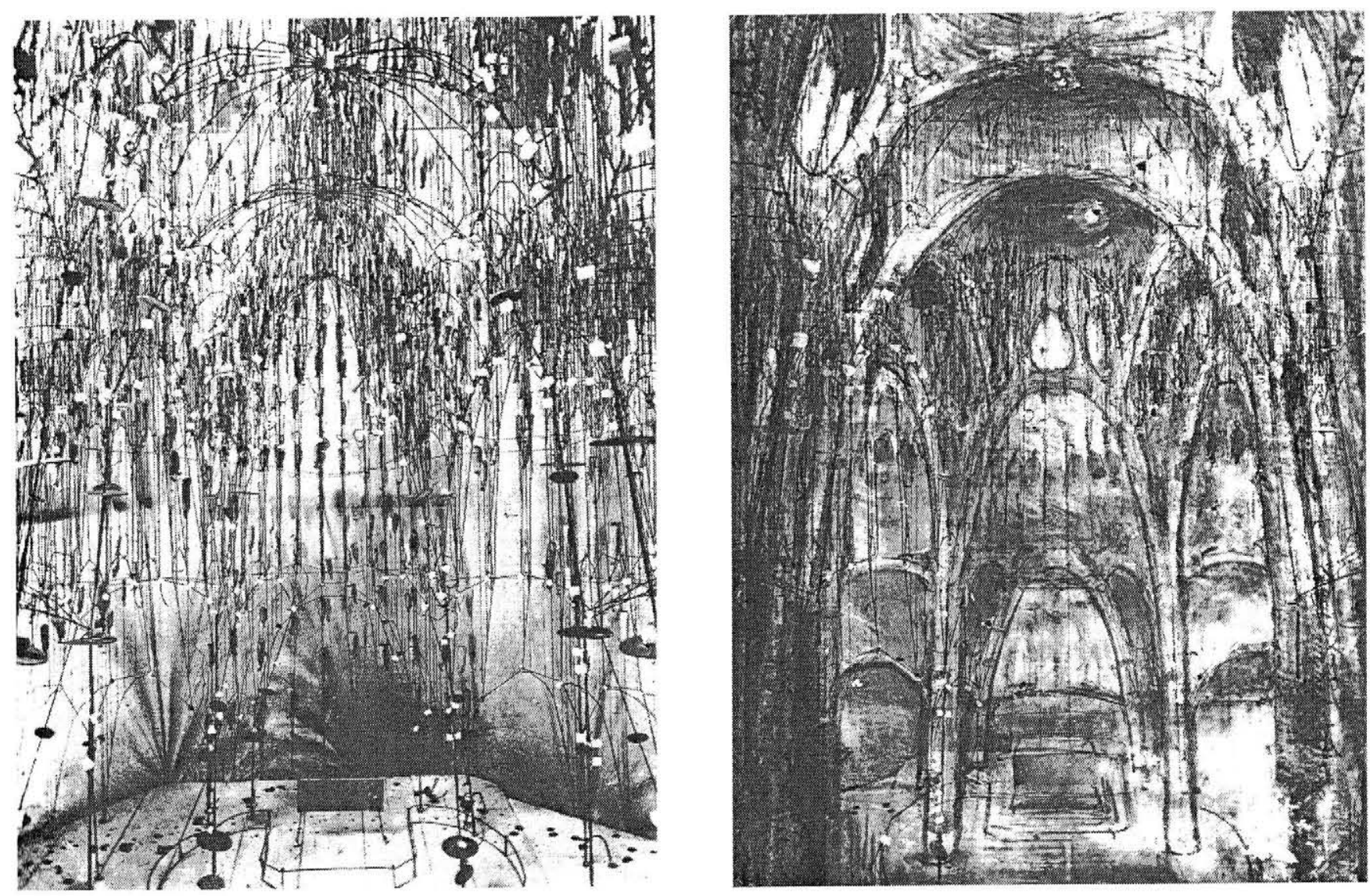

Figure 21. Left, inverted photograph of the hanging model, depicting the interior of the church of the Colonia Güell. Right, gouache drawings to show the interior space (Puig Boada 1976). 

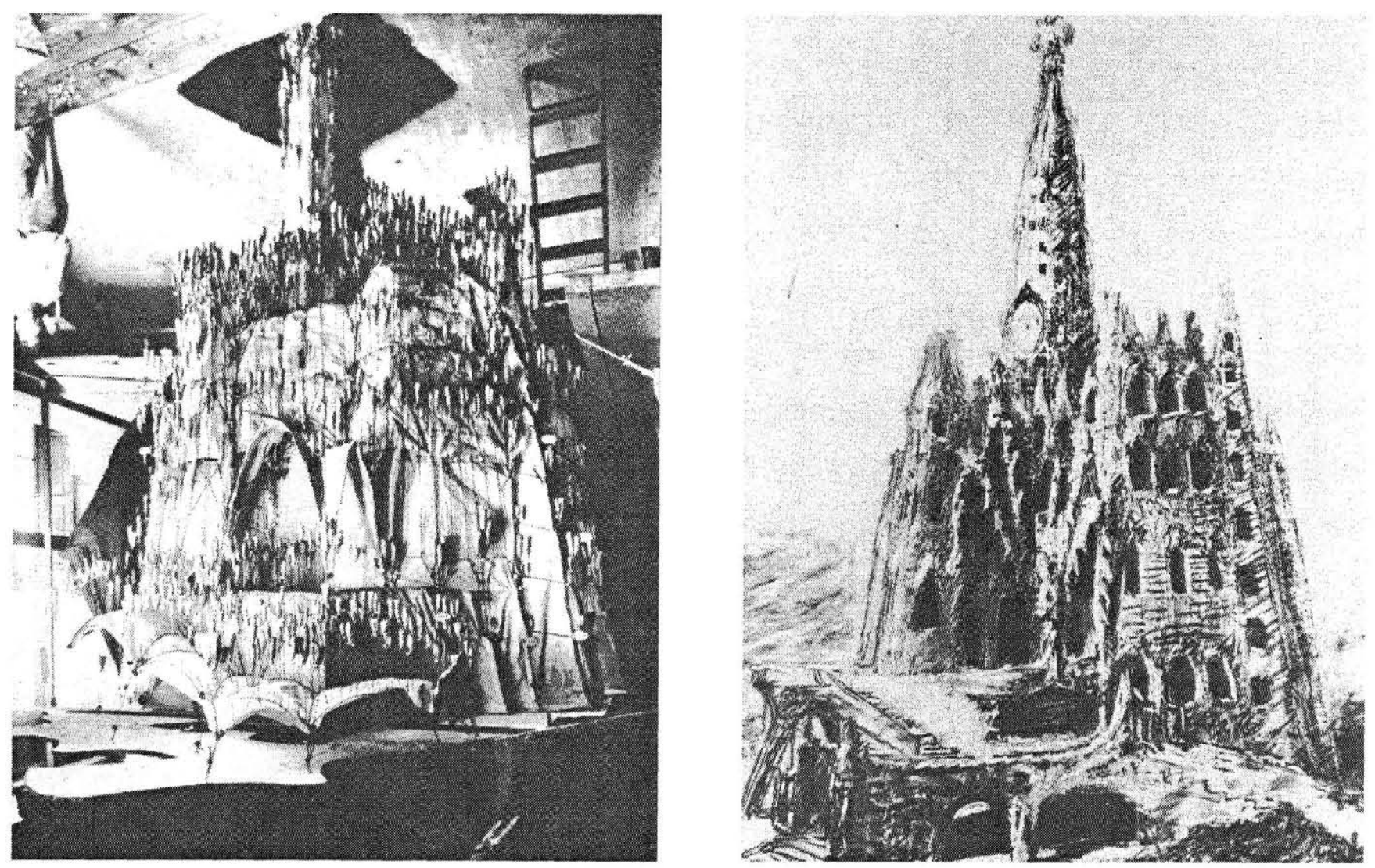

Figure 22. Left, inverted photograph of the complete model (note the man "hanging" on the upper left corner). Right, gouache drawing over a photograph of the model (Puig Boada 1976).

Gothic construction, Mohrmann in 1890 suggested the use of space hanging models ("Seilnetz") for studying the behaviour of Gothic vaulting (quoted by Graefe 1986).

A space-hanging model is an implicit application of the abovementioned "slicing technique." Hence, the hanging model for a cross vaulting is that shown in Figure 18, where each simple arch supports a section of the webs between the cross ribs, represented by the principal chains.

The model in Figure 18 is doubly symmetric. Gaudí posed himself the problem of totally asymmetric vaults on irregular supports. Without a continuous solution, he shifts from the vault problem to the problem of projecting a building. His investigations took place in the context of the works for designing and buildings the church at the Colònia Güell, which lasted eighteen year (10 years designing plus 8 years building the crypt, while the church remained unfinished). On very few occasions in the history of structures have so much time, effort and ingenuity been devoted to investigating an idea.

Similarly to the case of the transformed catenaries, the problem can't be solved directly and it is required to carry out iterations. First of all, the main skeleton is created, Figure 19, where the main cables represent the main thrust paths. This first model adopts a certain shape. Based on this configuration, the area and weight of the elements are calculated and the model is loaded using small sachets full of sand (Figure 20). These loads modify the shape of the model. The weight is then recalculated and the loads are adjusted in the model to match the newly calculated values. The model adopts a shape very approximate to the equilibrium shape, Figure 21 left. The resulting shape can be observed, and could be altered by changing the geometry and/or the loading. To show the volume ("give volume") of the model, Gaudi tried out different methods. One of them consisted of taking a photograph and drawing on it with gouache, as can be seen in Figure 21, right. On other occasions, he placed cloth or paper over the model before taking the photograph, which would be drawn on as before, Figure 22.

The hanging model functions like a "designing machine", as called by Collins (1971). When a satisfactory shape had been found, Gaudí attempted to represent space using one of the methods described in the previous paragraph. Lastly, he measured over the model to prepare the drawings. It is easily imagined how laborious the whole process is.

The original model was destroyed. In the 1980's, Graefe and Tomlow attempted to reproduce it. Tomlow wrote his doctorate thesis on the model and, lastly, published a book (Tomlow 1989) describing with great detail the model investigation and reconstruction works (nowadays the model is exhibited in the Sagrada Familia Museum, Barcelona).

\section{Hyperbolic Paraboloid Vaults}

Not only did Gaudí apply hanging models more generally and extensively than had been seen before, but also experimented with new geometric shapes for vaults. In particular, he used ruled surfaces: hyperbolic paraboloids and revolving hyperboloids. Thus, the vaults surrounding the crypt are the shape of a hyperbolic paraboloid, Figure 23. (These vaults have been studied in detail by González in various publications; see, for example, González 2002).

Once more, this is totally original contribution. Gaudí translates shapes that appeared in the $19^{\text {th }}$ century descriptive geometry manu- 

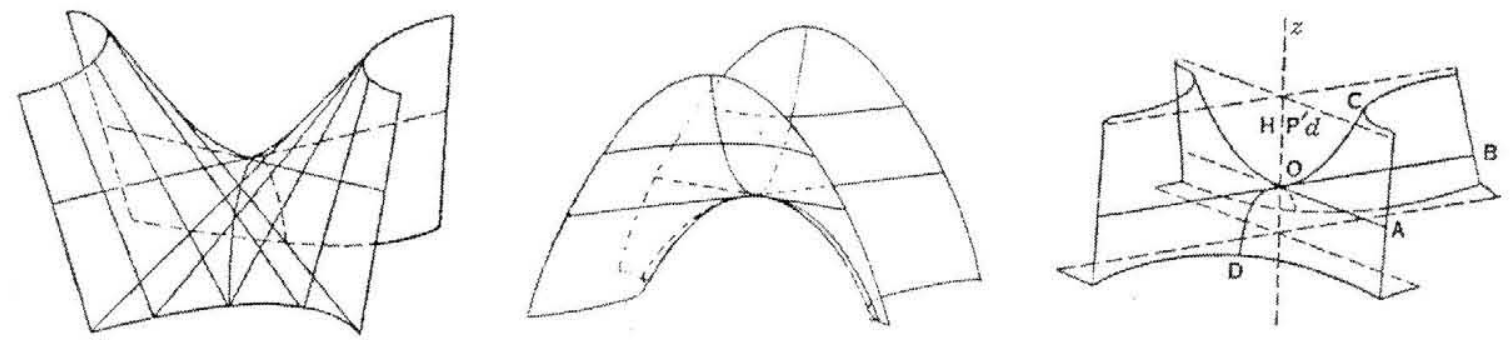

Figure 23. Hyperbolic paraboloid surfaces (Collins 1963).

als (e.g. Leroy 1855, quoted by Alsina and Gómez-Serrano 2002) to actual construction. In his conversations with his disciples, he expresses again and again his fascination about these shapes, for their geometric simplicity, for how easily they can be generated, since they are ruled surfaces.

The fact that he used them in the crypt also shows a perfect understanding of their structural behaviour. At first sight, those curvy shapes, Figure 24 (left), seem to contradict the essence of fabric construction. Fabric must work in compression and this is not possible if the vault is convex from underneath. In fact, the hyperbolic paraboloid is a surface with a negative Gaussian curvature at every point; this means that at every point the directions of principal curvature have different signs; if there is an apparent downwards curvature, no doubt there must be another curvature in the upwards direction, as can be seen in Figure 24 (right). This upwards curvature would allow an "arch" behaviour that would transfer the weight of the vault to the edges. It is evident that Gaudi was aware of this propriety and it is also evident that he "plays

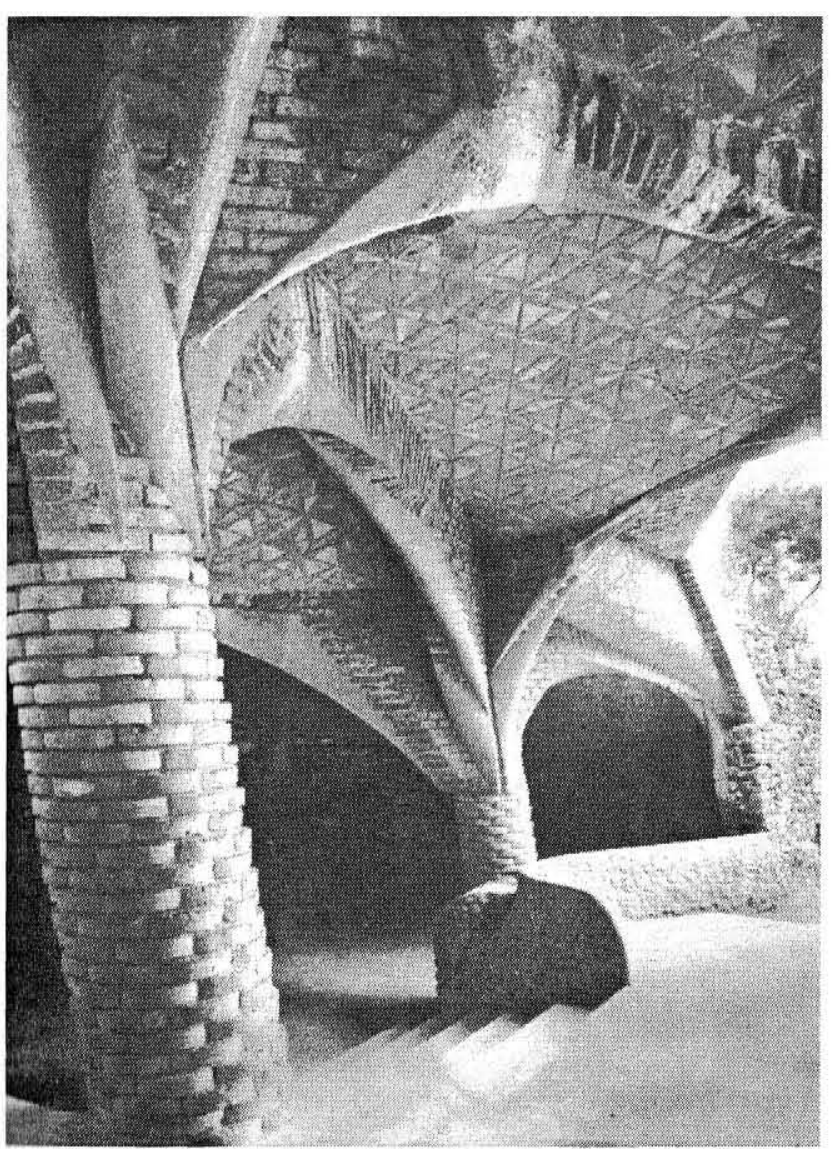

around" with the spectator, aiming to transmit a sensation of instability, which he achieves. It is the same game of the hanging capitals built by Gothic master masons (seeVillard d'Honnecourt), or the game of the fallen key of the mannerist arches (for example by Giulio Romano). It is a game reserved only for masters.

\section{La Sagrada Familia: The "Block" Model}

The final work by Gaudí, on which he worked until he died, is the Sagrada Familia Temple in Barcelona. The project for the church of the Colònia Güell had allowed Gaudí to study in depth the design and mechanics of arches and vaults of any shape. Surprisingly, at the Sagrada Familia he abandons the funicular models approach that he had exploited in the Colònia Güell project. The objective is different. The Colònia Güell project doesn't have references to historic architectural styles. Every aspect of it has an experimental and research character.

The Sagrada Familia has its origin in a previous neo-gothic project. Perhaps for this reason, in his project Gaudí proposes a

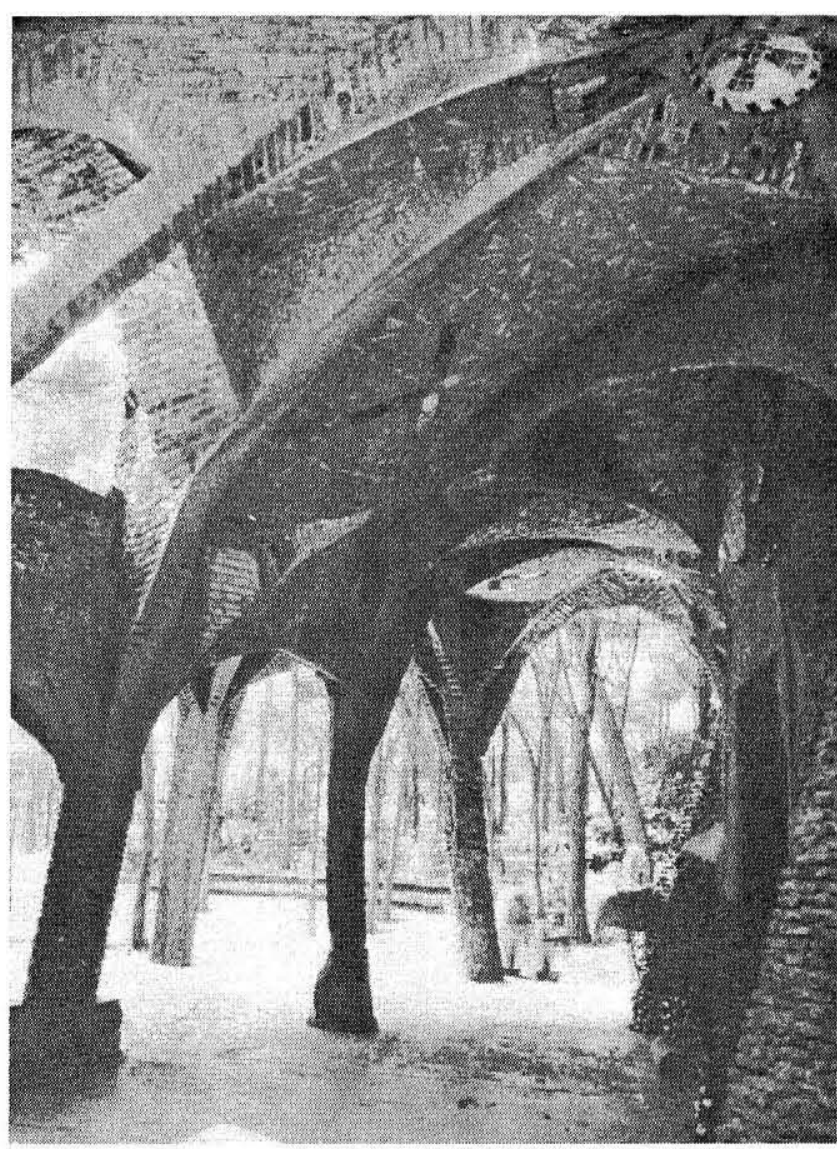

Figure 24. Hypar vaults of the portico of the church of the Colonia Güell. The vaults are so placed that it seems they are curved downwards (Tomlow 1989). 
perfection of the Gothic style. He seeks vertical loads, he seeks returning to the primitive basilica-like model (Sugrañes, 1923). In particular, he wants to get rid of what he called "the crutches" of the Gothic: flying buttresses and external buttresses. To make clear this point Sugrañes included in his article a comparison of the equilibrium between the cathedral of Cologne and the Sagrada Familia. Of course, it is not possible to transfer transverse loads in masonry structures without horizontal thrust, which in turn has to be resisted by some buttressing system and, though afterwards he ignores them, the necessary horizontal thrust is represented (Figure 25).

This objective of minimising the thrusts is present from the beginning of the long design process. In the first project from 1898 he tries to reduce the thrust, increasing the height of the cross and transverse ribs, looking for an almost pyramidal shape, Figure 26. The horizontal thrust is reduced, but is still present. To hold it without the need for buttresses, Gaudí inclines the columns, looking for the loads direction. This idea appears to be leading the project and Gaudí had tested and researched it in depth in the construction of the portico at the crypt in the church of Colònia Güell (see the inclined piers in Figure 24).

As we have seen before, there are few documents from which one can attempt to reconstruct the design and calculation process used by Gaudí. The only remains are a few photos of the model he built in his workshop and a few sketches and drawings (Gaudís workshop was destroyed during the Spanish war of 1936-39). With regard

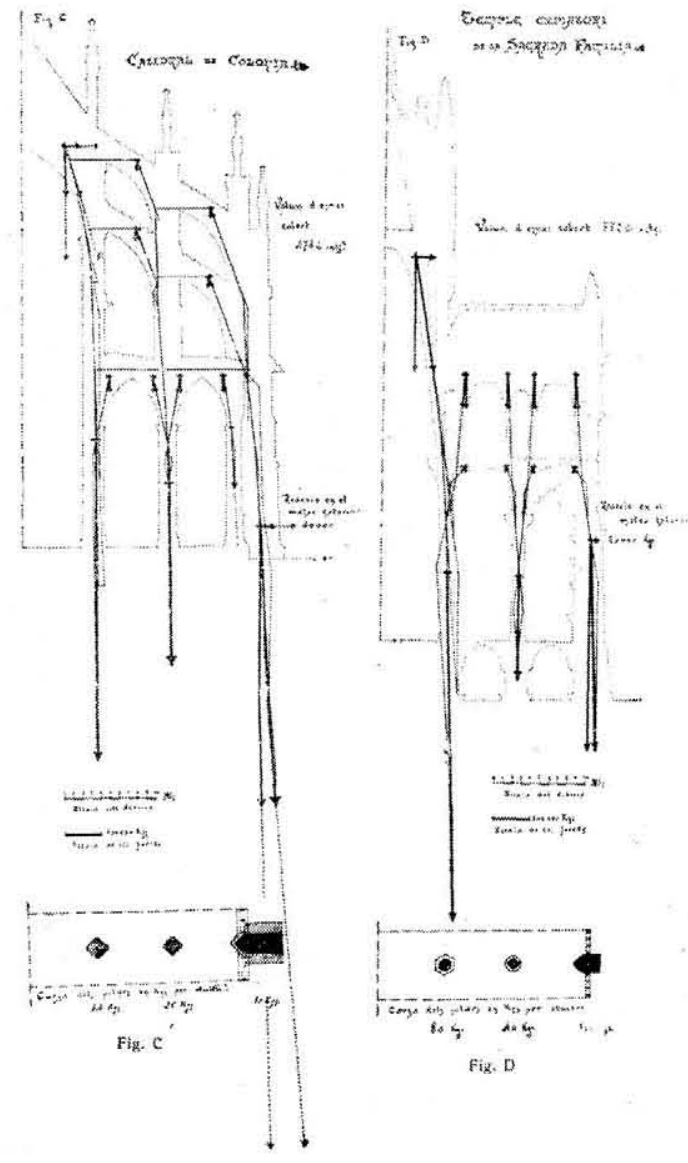

Figure 25. Comparison between the equilibrium systems in the cathedral of Cologne and the Sagrada Familia (Sugrañes 1923). to the structural calculations, luckily, his disciple Sugrañes published an article in 1923's "Anuario de la Asociación de Arquitectos de Cataluña", explaining the key lines of the design process and reproducing the details of the stability calculations for a typical section of the Sagrada Familia.

Gaudí abandons the funicular models and returns to graphical statics. However, it isn't the statics of funicular polygons. This is a different concept. The point is to calculate and equilibrate the loads

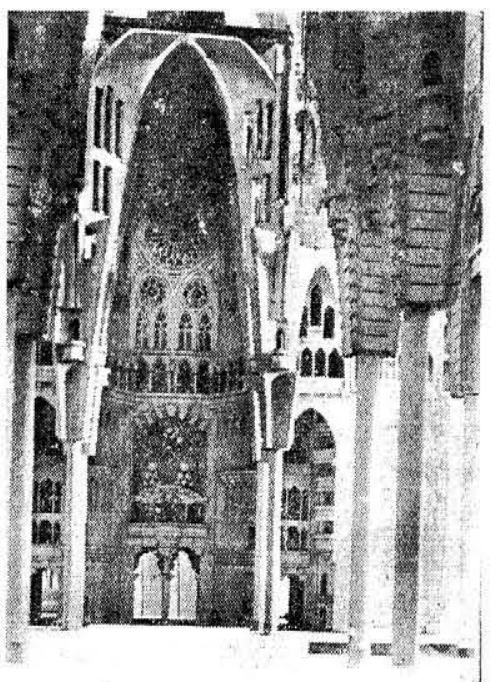

Figure 26. Model of one of the first designs for the nave of the Sagrada Familia (Rafols 1929). like in a balance. Sugrañes

article describes the final stage of the design of the grid of leaning columns supporting the central aisle, wall and part of the side aisles, for a typical span. The shapes of the roof, vaults, walls and windows have been defined prior to the calculation stage described in the article. Sugrańes does not comment on the process followed to define the shapes of the roof and vaults. However, the geometric complexity and building difficulty of the vaults, walls, pediments, etc., prove the existence of a long design process, previous to the final equilibrium analysis described by Sugrañes, Figures 27 and 28. The aim is to design the shape of the supporting skeleton ("tree") of columns. In Figure 29 may be seen one of the small
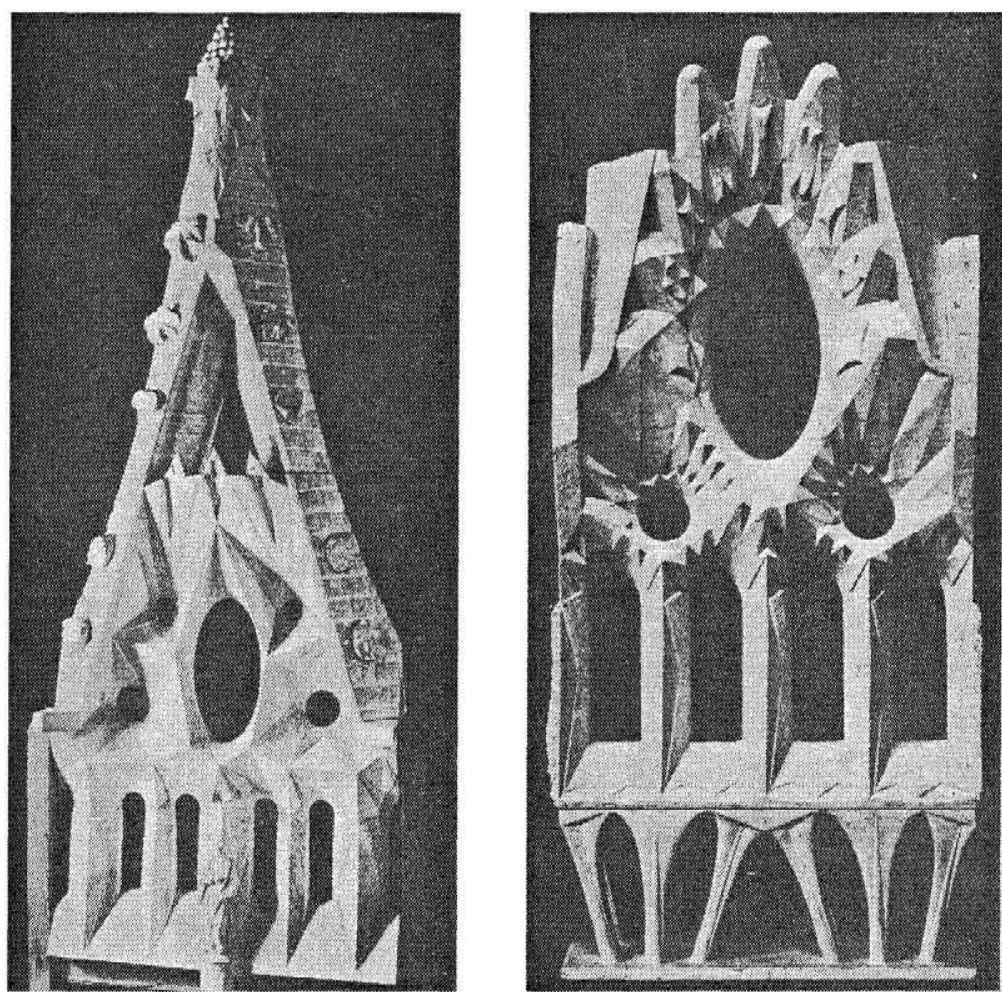

Figure 27. Pediment and window tracery of the walls of the main nave of the Sagrada Familia (Rafols 1929). 


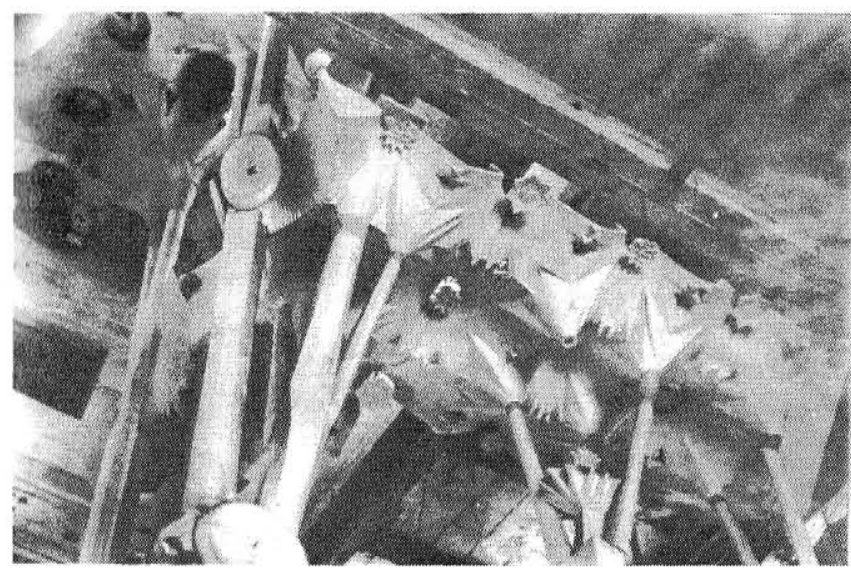

Figure 28. Partial view of the big block model of the Sagrada Familia in Gaudi's workshop (Puig Boada 1929).

plaster models and the big model constructed in Gaudís workshop, where he worked and lived.

The method for designing the columns is simple but very original. The main idea is to attain equilibrium between the various blocks that compose the structure, as it would be done in a set of scales. The structure is analysed in three main sections (central aisle, wall and side aisle). Their total weight and centre of gravity position are calculated. Each section is composed of a range of elements. The process is as follows: firstly, the weight and centre of gravity of each element is calculated (using the standard graphic statics methods, says Sugrañes) and, once these values are known, the weight and centre of gravity of each section is calculated.

The main problem is how to take these loads to the bases of the

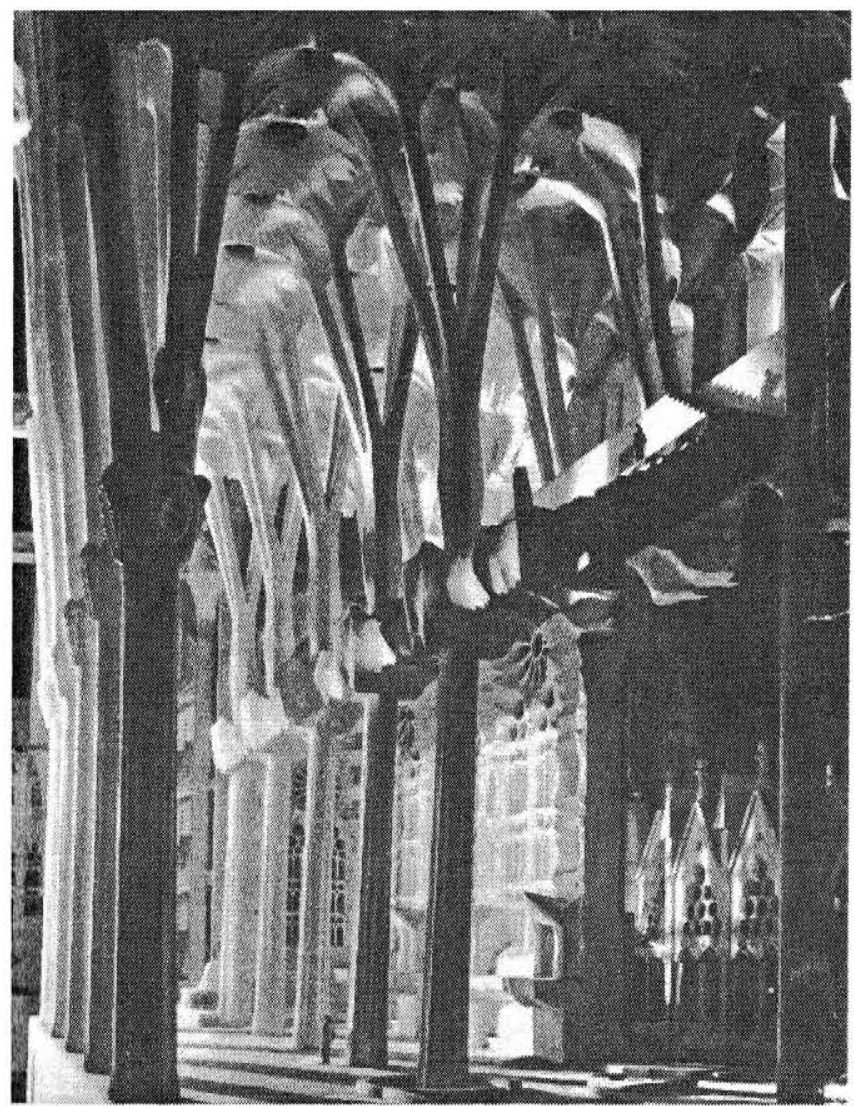

columns, which are already fixed in position (the crypt of the old neo-gothic design was already built); i.e. a skeleton of columns, a "tree" of columns, must be designed to be capable of collecting the loads from the centre of gravity of each section and transferring them to some fixed points on the ground. It is assumed in this equilibrium calculation that each section transmits its load vertically to the corresponding branch of the tree.

Thus, the concept of equilibrium is very different from the purely funicular system applied in the design of the church for Colonia Güell. This concept of equilibrium is what we could call global or for a "block" system structure, where each part, made up in turn of a series of elements, forms a block. These blocks, according to Sugrañes, don't interact with each other, but the branches of the skeleton seek to collect their concentrated weights at their centre of gravity. There is no arching action, no lateral thrust, and this is so, according to what Sugrañes says, because they would be made of a "concrete-like" material through the use of metal reinforcement. Since the majority of the elements, the vaults in particular, are defined by ruled surfaces, there would be no problem in placing straight reinforcing bars. In the case of the vaults, some of these bars could be used as centering during construction. Thus, the vaults could be constructed without traditional centering.

The weights and centres of gravity of the main parts are fixed. The base of the column was also fixed. Gaudí used a graphical method to design the tree that is going to collect the weights and take them to the bases of the columns. As it has been already mentioned, graphical statics methods become very complex for solving $3 \mathrm{D}$ equilibrium problems, since three projection planes are needed to define a segment in space. The webs of the nave and aisles of the Sagrada Familia have two symmetry planes,

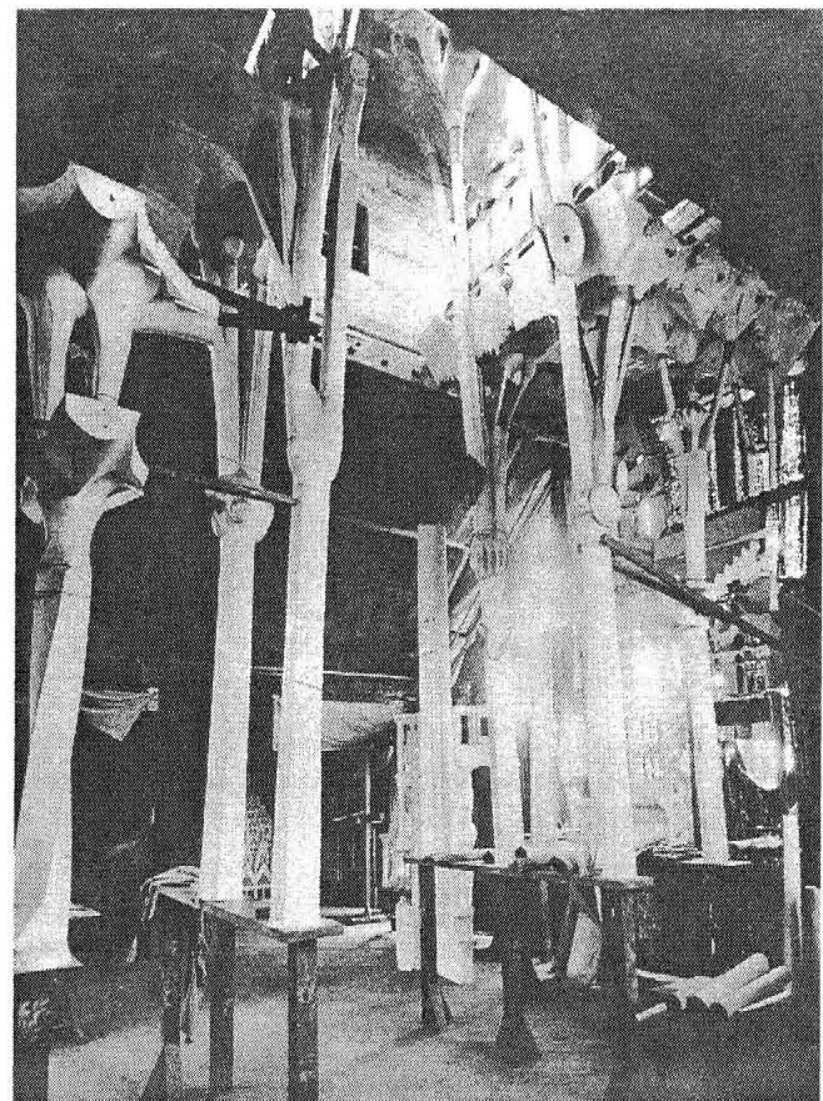

Figure 29. Left, view of the interior of a plaster model of interior of the Sagrada Familia. Right, big model in Gaudi's workshop (Puig Boada 1929). 


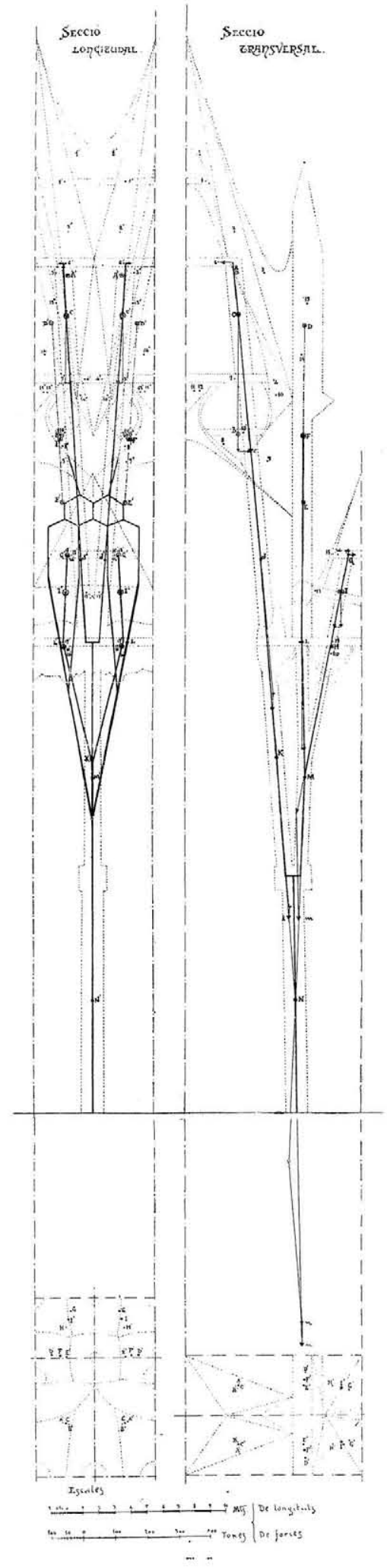

Figure 30. Graphical equilibrium analysis of the main nave of the Sagrada Familia (Sugrañes 1923).

simplifying the problem. Graphical statics are easier to apply in this case. Gaudí studied one-half of the aisle, which also has a vertical symmetry plane, perpendicular to the axis of the aisle. Given these two properties, it is easy to check various equilibrium solutions projecting on two planes. The final equilibrium solution is represented in Figure 30.
Of course, horizontal thrust is needed when compensating leaning forces: loads can't be translated horizontally (in the absence of bending elements such as beams) without an arch action. Given the verticality of the project, these thrusts are small, but unavoidable. Sugrañes assumes that horizontal thrusts are developed in the symmetry plane of the central and lateral aisles. These thrusts determine the inclination of the columns. (Some columns are subdivided inside the plane defined in the general scheme, but equilibrium is guaranteed by the symmetry that always equilibrates the horizontal thrusts.) Then, the column weights are calculated, and, finally, after a few trials, the equilibrium skeleton can be drawn.

The most polemical aspect of this process could perhaps be the assumption that vaults and roofs don't generate any thrust. The thin vaults (not so thin in this case: Sugranes calculates the weight based on a thickness of $450 \mathrm{~mm}$ ), whether or not they are reinforced, require certain edge conditions to obtain an equilibrium state, acting as a membrane (disregarding bending). This is the expected behaviour for a well-designed shell or vault. The edge forces, which are thrusts mainly, can be equilibrated by the reinforcement in the floors. The weight of the vaults over the aisles is small and, thus so is the thrust they originate. Nevertheless, those thrusts exist and they must be compensated.

Sugrañes' statement about the lack of thrust due to the use of reinforcement therefore isn't correct. We can't be sure that Sugrańes has fully understood the Master's ideas, as the case usually is with regards to Gaudí. Given the extensive experience Gaudí had designing and building thin vaults, it is very likely that Gaudi knew about the existence of the thrust but ignored it in the design of the main skeleton because it is secondary in the full scheme of equilibrium.

In fact, the geometric shape of the project shows that Gaudí did consider the existence of thrust and the need to transfer them as vertically as possible, to maintain his general scheme. Gaudí used, first, a typically Gothic solution: he eliminates the buttress by greatly increasing the vertical load (Huerta 2004). This system was exploited in the design of the Cathedral in Palma de Mallorca, where the slender columns in the aisle resist the thrust from the lateral aisle thanks to the large load added on the ribbed arches and keys in the central aisle (Rubió i Bellver 1912)

In the Sagrada Familia, the enormous weight of the pediments and the tracery of the windows is what equilibrates the main part of the thrust. But, Gaudí, even though he criticises the Gothic style, incorporated eventually "hidden" flying buttresses which may be seen in the cross sections and, also, in the roof model, Figure 31. Their function would be to transfer the remnant thrust from the vaults and roof to the columns of the lateral aisle.

\section{Gaudí and the Equilibrium Approach}

Every single analysis and design method used by Gaudí is based on finding equilibrium solutions. In a more technical jargon: Gaudí only uses the equilibrium equations of statics. Some times he used models, some others he uses graphical statics, but he only used these equations. The other two structural equations, which refer to material properties (constitutive equations) or to the geometry of deformation (compatibility equations) are fully absent.

Gaudí is applying the main idea of the "old vault theory", developed and applied in the $18^{\text {th }}$ and $19^{\text {th }}$ centuries. This theory is based in finding equilibrium configurations where the masonry 

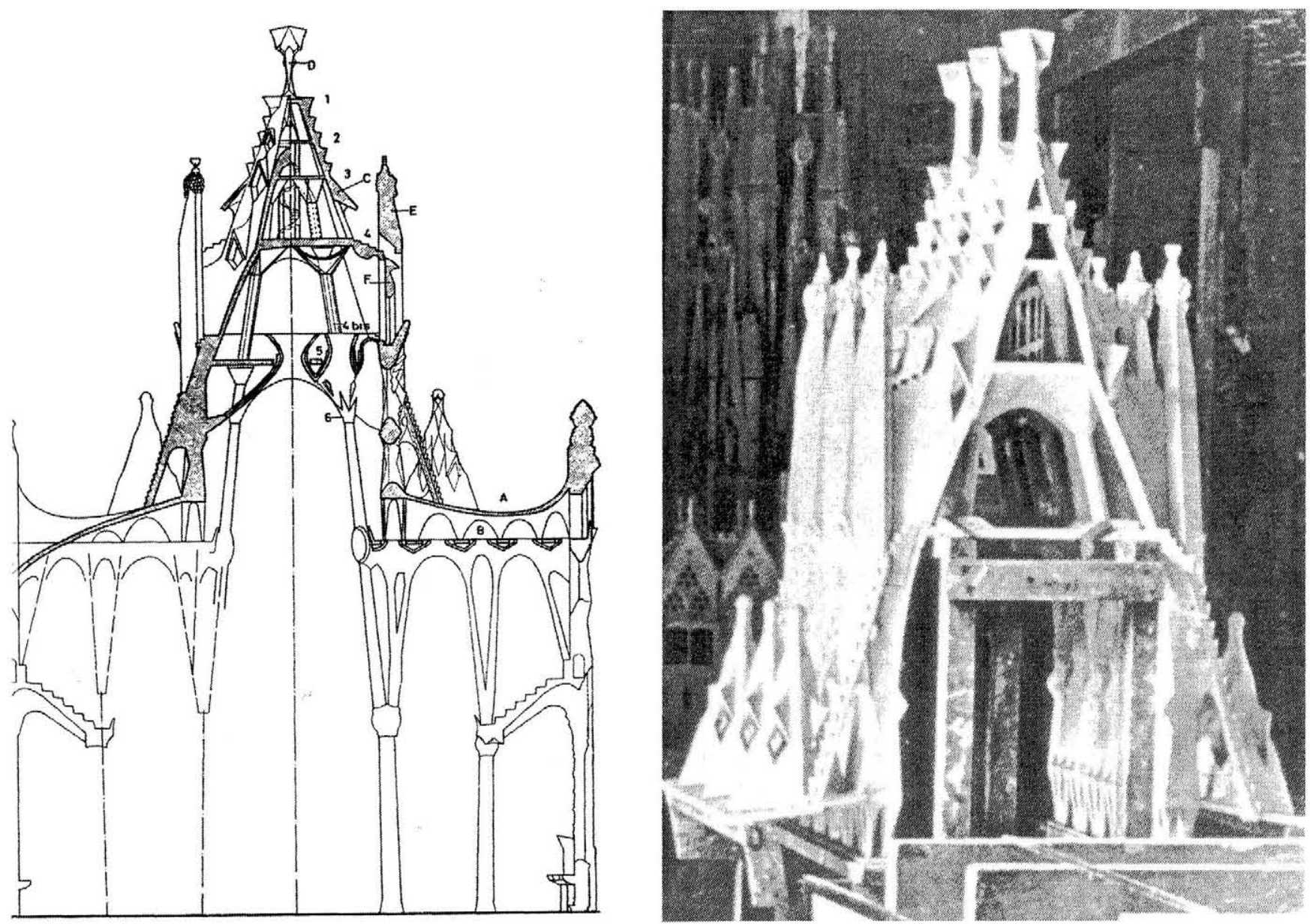

Figure 31. Gaudi placed "bidden" Aying buttresses to absorb some of the horizontal thrusts of the roof. Right, section of the Sagrada Familia (Bergós 1953). Right, model of the roof (Giralt-Miracle 03).

acts in compression. A safety factor was included in the design by "covering" the skeleton of forces, the lines of thrust, with enough masonry to obtain a safety factor to account for small movements or small variations in the loading (same as Gaudí did in his design for the church at Colònia Güell).

At the end of the $19^{\text {th }}$ century, this approach was considered merely approximate, if not incorrect. In effect, the thickening of the skeleton allowed the existence of not one "skeleton of forces", but of an infinite number of them. Internal forces can't be determined using the equilibrium equations alone and there are an infinite number of suitable force paths or "skeletons" inside the masonry, every one of them in equilibrium with the loads. Indeed, in the case of the church at Colonia Güell, the current equilibrium state is very different from that calculated with the model as the church was never completed and what remains is the crypt. The inclined columns do not receive the load of the church structure; however, it is a possible an equilibrium solution due to the aforementioned "thickening" of the masonry around the funicular of forces.

Engineers at the end of the $19^{\text {th }}$ century, deeply influenced by Navier's "elastic philosophy" (defined by Heyman, 1999a, as Navier's "straitjacket"), found this indetermination to be a big mistake. They wanted to find the actual state of the structure, the actual way the loads were carried to the ground. The solution was, then, to apply elastic analysis, i.e. to add the material (linear-elastic) and compatibility (continuity of elements, boundary conditions) equations to the equilibrium equations, previously used on their own.

Thus, to calculate the arch of a bridge, made up of independent voussoirs and standing on ground that would, inevitably, give slightly after striking the centering, a continuous, homogeneous, isotropic course of a perfectly elastic material was considered. Such arch would be considered to be perfectly built in, rotation and translation impeded. This way a unique solution was obtained, a unique "elastic" line of thrust representing the "actual state of the arch". However, cracks often appeared in masonry arches after striking the centering, proving that the calculated "actual" state of the arch wasn't possible. There was no answer for this problem. The evident contradiction, the fact that the calculated state did not at all represent the actual physical structure, was almost systematically ignored, with only some exceptions such as Swain 1927. Not withstanding this, it was a fact that those bridges designed using elastic calculations were standing, just like those calculated using the old theory.

The contradiction was only resolved with the development of the Plastic Theory (or Limit Analysis, or Fracture Theory). The same disparity between calculations and actual deflections in structures was observed in the systematic tests on frames carried out by the Committee for the Development of Steel Structures in UK in the 1920s. Plastic Theory was thus borne because Elastic Theory couldn't account for what was being observed. The development of Plastic 
Theory reached its final point with the proof of the Fundamental Theorems (in Russia, in 1936, by Gvozdev; rediscovered in the 1950's; cf. Heyman 2001).

The Safety Theorem resolved the dilemma of the impossible task of finding the "actual" state of the structure: if it is possible to find a distribution of internal stresses in equilibrium with the external loads that doesn't violate the yield condition of the material, the structure will be safe, it won't collapse. The equilibrium situation does not have to be the "actual" one; it just has to be possible. The structure is, at least, as intelligent as the designer and before collapsing it will find the projected equilibrium situation (there could be many others and this Theorem justifies the stability of the crypt in the church at Colònia Güell).

In fact, the Safety Theorem leads to what Heyman has called the "equilibrium approach": to design or analyse buildings made of a "plastic" material we can work exclusively with equilibrium equations, checking afterwards that they don't violate the limit condition of the material (in a frame, for instance, checking that the ultimate moment capacity is not exceeded in any section). The elastic solution is a "possible" solution and is, also, safe, but it is not more exact or real as any other equilibrium solution.

The Plastic Theory was developed for materials like steel that have a large enough plastic range to resist rotations localised in specific places (plastic hinges). It was soon noticed that it could be applied to reinforced concrete also (for elements with limited reinforcement). Professor Heyman has pointed out that, in fact, the Safe Theorem can be applied to any structure built with a material that shows a certain "plasticity", allowing the formation of hinges, even if they are partial, and, of course, in the absence of local or global instability. We are talking about non-brittle, hard materials. To the aforementioned we can add timber and masonry (Heyman 1995; Huerta 2001), even if this seems surprising.

For masonry, the yield condition of the material is that it must work in compression and, to achieve that, the thrust must always be contained inside the structure. The Safe Theorem can now be phrased as follows: if it is possible to draw a group of lines of thrust in equilibrium with the loads inside the masonry, the structure is safe. The stability condition is purely geometrical and the safety of masonry architecture depends on its geometrical form.

The approach used by Gaudí in designing his buildings is an equilibrium approach and it is fully justified by the Safe Theorem. In fact, Gaudí was the first one to draw all the consequences of the equilibrium approach: he didn't limit himself to verifying structures previously designed, as had been the practice until then, but he deliberately designed equilibrated structures. Of course, there are infinite solutions and Gaudí considered the mechanical aspect as one of the many conditions that an architectural project must meet and criticised strongly the formal determinism of what he termed "funicularism."

\section{Acknowledgements}

This paper is based on a Lecture delivered at The School of Architecture of Madrid, within the Year Gaudí 2002. An earlier version of the text was published in Spanish in Ingenieria Civil 129,2003 . The present text is a completed and revised version. I thank Alejandra Albuerne for the English translation of the Spanish manuscript.

\section{References}

Benvenuto, E. (1991). An Introduction to the History of Structural Mechanics. Part II: Vaulted Structures and Elastic Systems. New York/Berlin: Springer Verlag.

Beranek, W.J. (1988). Understanding of structures. In R.M. Lemaire \& K. Van Balen, Eds.), Stable-Unstable? Structural Consolidation of Ancient Buildings (pp 29-44). Leuven: Leuven University Press.

Bérard, J.-B. (1810). Statique des Voûtes. Paris: Chez Firmin Didot.

Bergós Massó, J. (1953.) Materiales y Elementos de Construcción: Estudio Experimental. Barcelona: Bosch.

Bergós Massó, J. (1965). Tabicados Huecos. Barcelona: Colegio de Arquitectos de Cataluña y Baleares.

Bouguer, P. (1734). Sur les lignes courbes propres a former les voûtes en dome. Mémoires de l'Académie Royale de Sciences de Paris, 149-166.

Codinachs, M. (Ed.) (1982). Antoni Gaudi.: Manuscritos, Articulo, Conversaciones y Dibujos. Madrid: Colegio Oficial de Aparejadores y Arquitectos Técnicos.

Collins, G.R. (1963). Antonio Gaudí: Structure and form, Perspecta, 8, 63-90.

Collins, G.R. (1966). Antonio Gaudí: Estructura y forma, Hogary Arquitectura, 34-52.

Collins, G.R. (1971). Antonio Gaudí and the uses of technology in modern architecture. In Civil Engineering: History, Heritage and the Humanities, Vol 1: Selected Papers from the First National Conference. Princeton, N.J.: Princeton University Press.

Culmann, K. (1866). Die Graphische Statik. Zürich: Meyer und Zeller.

Frézier, A.F. (1754-69, Rev ed. 1737). La Théorie et la Pratique de la Coupe de Pierres et des Bois. Strasbourg/Paris: Charles-Antoine Jombert.

Giralt-Miracle, D. (2002). Gaudi: La Búsqueda de la Forma. Espacio, Geometria, Estructura y Construcción. Barcelona: Lunwerg.

González Moreno-Navarro, J.L., \& Casals Balagué, A. (2002). Gaudí y la Razón Constructiva. Un Legado Inagotable. Madrid: Akal.

Graefe, R. (1986). Zur formgebung von bogen und gewölben, Architectura, 16, 50-67.

Gregory, D. (1697). Catenaria, Philosophical Transactions of the Royal Society, 19(231), 637-652.

Heyman, J. (1998). Hooke's cubico-parabolical conoid, Notes and Records of the Royal Society of London, 52(1), 39-50.

Heyman, J. (1995). The Stone Skeleton: Structural Engineering of Masonry Architecture. Cambridge: Cambridge University Press.

Heyman, J. (1999a). Navier's straitjacket, Architectural Science Review, $42,91-95$.

Heyman, J. (1999b). The Science of Structural Engineering. London: Imperial College Press.

Heyman, J. (2003). Wren, Hooke and partners. In S. Huerta (Ed.), Proceedings of the First International Congress on Construction History (pp. 3-9). Madrid: Instituto Juan de Herrera.

Hooke, R. (1675). A Description of Helioscopes, and some other Instruments. London: John Martyn.

Huerta, S. (2001). Mechanics of masonry vaults: The equilibrium approach. In P.B. Lourenço \& P. Roca (Eds.), Historical Constructions 2001: Proceedings of the $3^{\text {rd }}$ International Seminar (pp. 47-69). Guimaraes: Universidade do Minho.

Huerta, S. (2004). Arcos, Bóvedas y Cúpulas: Geometría y Equilibrio en el Cálculo Tradicional de Estructuras de Fábrica. Madrid: Instituto Juan de Herrera.

Inglis, C. (1951). Applied Mechanicsfor Engineers. Cambridge: Cambridge University Press. 
Koerner, C. (1901). Gewölbte Decken (Handbuch der Architektur, Dritter Teil. 2 Band, Heft 3, b). Stuttgart: Arnold Bergsträsser Verlagsbuchhandlung.

I croy, C.F.A. (1855). Traité de Géométrie Descriptive. Paris: MalletBachellier.

Martinell, C. (1969). Convesaciones con Gaudi. Barcelona: Ediciones Punto Fijo.

Maxwell, J.C. (1864). On the calculation of the equilibrium and stiffness of frames, Philosophical Magazine, 27, 294-300.

Méry, E. (1840). Mémoire sur l'equilibre des voûtes en berceau, Annales des Ponts et Chaussées, 50-70, planches 133-134.

Moseley, H. (1835). On the equilibrium of the arch (Read Dec. 9, 1833). Cambridge Philosophical Transactions, 5, 293-313.

Moseley, H. (1838). On the theory of the equilibrium of a system of bodies in contact, Cambridge Philosophical Transactions, 6, 463-491.

Otto, F. (1983). Der bogen, Arcus, no 2, no 3, no 4, 71-81, 119-127, 199-207.

Planat, P. (1887). Pratique de la Mécanique Appliquée a la Resistance des Matériaux. Paris: La Construction Moderne.

Planat, P. (1906). L'Art de Bâtir. Vol. 3: Voûtes en Maçonnerie, Voûtes d'Eglises, Fléches et Tours, Béton Armé, Silos. Paris: Librairie de la Construction Moderne.

Puig Boada, I. (1929). El Temple de la Sagrada Familia. Barcelona: Editorial Barcino.

Puig Boada, I. (1976). L'Església de la Colònia Güell. Barcelona: Lumen.

Poleni, G. (1748). Memorie Iistoriche della Gran Cupola del Tempio Vaticano. Padova: Nella Stamperia del Seminario.

Rankine, W.J.M. (1858). A Manual of Applied Mechanics. London: Charles Griffin.

Rubió i Bellver, J. (1912). Conferencia acerca de los conceptos orgánicos, mecánicos y constructivos de la Catedral de Mallorca, Anuario de la Asociación de Arquitectos de Cataluña, 87-140.
Rubiói Bellver, J. (1913). Dificultats per a arribar a la sintessis arquitectónica, Anuario de la Asociación de Arquitectos de Cataluña, 63-79.

Snell, G. (1846). On the stability of arches, Minutes and Proceedings of the Institution of Civil Engineers, 5, 439-476, láms. 27-40.

Sugrañés Gras, D. (1923). Disposició estàtica del temple de la Sagrada Familia, Anuario de la Asociación de Arquitectos de Cataluña, 17-36.

Swain, G.F. (1927). Structural Engineering: Stresses, Graphical Statics and Masonry. New York: McGraw-Hill.

Tappe, W. (1818-21). Darstellung einer euen, äußerst wenig Holzerfordenden und höchst feuersicheren Bauart. Essen: Baedeker.

Tarragó Cid, S. (1974). Gaudí entre la estructura y la forma, $A+U, \mathrm{n}^{\circ}$ 86 (extra issue), 13-59.

Tarragó Cid, S. (Ed.) (1991). Antoni Gaudi. Barcelona: Ediciones del Serbal.

Tomlow, J. (1989). Das Modell. Antoni Gaudis Hängemodell und seine Rekonstruktion. Neue Erkenntnisse zum Entwurf für die Kirche der Colònia Güell. Stuttgart: Universität Stuttgart, Institut für Leichte Flächentragwerke. Universität Stuttgart. (text in German, English and Spanish)

Tomlow, J. (1993). Die kuppel des gießhauses der firma Henschel in Kassel (1837): Eine frühe anwendung des entwurfsverfahrens mit hängemodellen, Architectura, 23, 151-72.

Villarceau, A.Y. (1853). Sur l'Etablissement des Arches de Pont, Envisagé au Point de Vue de la plus Grande Stabilité. Paris: Imprimerie Impériale.

Wittmann, W. (1879). Zur theorie der gewölbe, Zeitschrift für Bauwesen, 29, 61-74.

Young, T. (1845; Rev ed. 1807). A Course of Lectures on Natural Philosophy and the Mechanical Arts: A New Edition, with references and notes by the Rev. P. Kelland. London: Taylor and Walton. 